\title{
Flightless Hawaiian Hemerobiidae (Neuroptera): Comparative morphology and biology of a brachypterous species, its macropterous relative and intermediate forms*
}

\author{
CAtherine A. TAUBER ${ }^{1}$, Maurice J. TAUBER ${ }^{1}$ and Jon G. GIFFIN ${ }^{2}$ \\ ${ }^{1}$ Department of Entomology, Comstock Hall, Cornell University, Ithaca, NY 14853, USA; Research Associate, Hawai‘i Biological \\ Survey, Bernice P. Bishop Museum, Honolulu, Hawai`i, USA; e-mail: cat6@cornell.edu \\ ${ }^{2}$ Research Associate, Science Department, Bernice P. Bishop Museum, Honolulu, Hawai`i, USA; e-mail: giffinjon@yahoo.com
}

Key words. Neuroptera, Hemerobiidae, Micromus usingeri, M. longispinosus, Hawaiian endemic, evolution of brachyptery, larvae, life history, morphology

\begin{abstract}
Five flightless species of Micromus are known from the Hawaiian Archipelago; only one, the rare Micromus usingeri, is reported from the Island of Hawai'i. Herein, we report the natural occurrence of intermediates between this brachypterous species and its near relative, the macropterous Micromus longispinosus. We compare some morphological and life-history characteristics of the two species and the intermediates. Our study shows that: (1) The two closely related species are broadly distributed on Hawai ${ }^{i}$, but they appear to be allopatric altitudinally. (2) M. usingeri is associated with a cool, misty, high-altitude environment, M. longispinosus with warmer, rainy conditions at lower elevations. The intermediates occur in both types of situations and generally at intermediate elevations. (3) The macropterous M. longispinosus has large, oblong, flexible, membranous forewings and hind wings. In contrast, the brachypterous $M$. usingeri has convex, shortened, elytra-like forewings with reticulate venation, and very small, thick, triangular, stub-like hind wings with greatly reduced venation. The wings of intermediate specimens exhibit a broad range of variation between the two species. (4) Several characteristics of wing venation are highly correlated with reduced wing size; others are not. (5) Aside from the wings, adults of M. usingeri and M. longispinosus differ in relatively few morphological features, most notably the antennal and metatibial length, prothoracic length, mesothoracic length and width, and the length of the spine-covered process on the posteroventral margin of the male T9+ectoproct. The intermediate specimens are variable in adult characteristics, but they generally fall between the two species. (6) Egg size and larval characteristics (except the body length of the fully-fed first and third instars) do not differ between the two species. (7) The evolution of the wing variation is discussed.
\end{abstract}

\section{INTRODUCTION}

Secondary loss or reduction of wings - and the resulting loss of flight - has occurred numerous times among pterygote insects (e.g., Roff, 1990; Wagner \& Liebherr, 1992). Within the order Neuroptera, wing reduction is known from five of the 17 families (Oswald, 1996). It is particularly prevalent among the Hemerobiidae (brown lacewings) - the only family in the order in which both sexes express flightlessness. Eleven species within five hemerobiid lineages show hind-wing reduction or loss; this pattern indicates that brachyptery and flightlessness have evolved repeatedly in the group (Oswald, 1996).

Among insects, the incidences of wing reduction and loss of flight tend to increase at high altitudes and on isolated landmasses surrounded by inhospitable terrain or water (Roff, 1990; Gillespie \& Roderick, 2002). Therefore, it is not surprising that numerous remarkable cases are found among the endemic radiations of alate insects that colonized the Hawaiian Islands (Carlquist, 1980; Howarth \& Mull, 1992). Of the 23 known species in the presumed monophyletic radiation of endemic Hawaiian hemerobiids (subfamily Microminae, genus Micromus), five have undergone striking modifications of the forewings, drastic hind-wing reduction, and loss of the ability to fly (Perkins, 1899; Zimmerman, 1957). Only three of the Hawaiian Islands are known to have flightless hemerobiids, and each of the five flightless hemerobiid species has a relatively restricted, high-elevation distribution on only one island. Thus, it is reasonable to conclude that flightlessness evolved independently in at least three, and perhaps all five, of these species (e.g., see Zimmerman, 1957; Oswald, 1996).

The evolutionary and ecological pathways involved in wing reduction or loss in insects have stimulated much research and discussion (see reviews by Southwood, 1977; Roff, 1990; Wagner \& Liebherr, 1992; Zera \& Denno, 1997). Although some of the environmental conditions that may favor wing reduction in Hemerobiidae have been considered (Zimmerman, 1957; Penny \& Sturm, 1984; Oswald, 1996), an understanding of the selection pressures and trade-offs involved in its evolution in this family is far from realized.

* This paper is dedicated to the memory of Professor Robert L. Usinger (1912-1968), University of California, Berkeley - an extraordinary field biologist, systematist, teacher and mentor. 
TABLE 1. Specimens examined and measured; all are from the Island of Hawai' $i$, Hawai' $i$.

\begin{tabular}{|c|c|c|}
\hline Collection data & Altitude $(\mathrm{m})$ & Forest type \\
\hline \multicolumn{3}{|l|}{ Micromus usingeri $(\mathrm{N}=5)$} \\
\hline $\begin{array}{l}\text { Humu'ula, } 1.6 \mathrm{k} \mathrm{N} \\
\text { 30.vii.1935, R.L. Usinger }(1 \delta \text {, holotype })^{1}\end{array}$ & 2,073 & Subalpine dry: mamane (Sophora) forest \\
\hline $\begin{array}{l}\mathrm{Pu}^{6} \text { u Wa'awa'a, SSW of Kileo } \\
\text { 12.v.1998, M.J. \& C.A. Tauber }(2 q)^{2}\end{array}$ & 1,920 & Subalpine dry: 'ohi'a (Metrosideros) forest \\
\hline $\begin{array}{l}\text { Hualalai summit, nr. Luamakami Crater } \\
\text { 16.x.1997, C.P. Ewing (1 } 9)\end{array}$ & 2,420 & Subalpine dry: 'ohi'a (Metrosideros) forest \\
\hline $\begin{array}{l}\text { Mauna Kea Forest Reserve, Kaluamakani (Dubautia arborea) } \\
\text { 8.v.2002, J.G. Giffin (1 } q \text { ) }\end{array}$ & 2,315 & Subalpine dry: mamane (Sophora) forest \\
\hline \multicolumn{3}{|l|}{ Micromus longispinosus $(\mathrm{N}=9)^{3}$} \\
\hline $\begin{array}{l}\text { Upper Waiakea Forest Reserve, Stainback Hwy, Pole \#54 } \\
\text { 11.iv.1999, J.G. Giffin (1 } 9 \text { ) }\end{array}$ & 1,220 & $\begin{array}{l}\text { Montane wet: 'ohi'a/hapu'u } \\
\quad(\text { Metrosideros/Cibotium) tree fern forest }\end{array}$ \\
\hline $\begin{array}{l}\text { Upper Waiakea Forest Reserve, Powerline Rd., Kipuka } \\
\text { 7.vii.2001, J.G. Giffin (1 } \text { ㅇ) }\end{array}$ & 1,765 & Montane wet: 'ohi'a (Metrosideros) forest \\
\hline $\begin{array}{l}\text { South Kona Forest Reserve, Kukuiopa'e Section } \\
\text { 26.iv.2000, J.G. Giffin }(1 \hat{\delta}, 1 \uparrow)\end{array}$ & 1,525 & $\begin{array}{l}\text { Montane mesic: koa/ohi'a } \\
\quad(\text { Acacia/Metrosideros) forest }\end{array}$ \\
\hline $\begin{array}{l}\text { Kapapala/Ka'u Forest Reserve, Koa Management Area } \\
\text { 17.viii.2001, J.G. Giffin }\left(3 \delta^{\dagger}, 1 q\right)\end{array}$ & 1,560 & $\begin{array}{l}\text { Montane mesic: koa/ohi'a } \\
\text { (Acacia/Metrosideros) forest }\end{array}$ \\
\hline \multicolumn{3}{|l|}{ Intermediate $(\mathrm{N}=7)$} \\
\hline $\begin{array}{l}\text { Pu'u Wa'awa'a, Forest Bird Sanctuary (Metrosideros polymorpha) } \\
\text { 24.iv.2002, J.G. Giffin (1 } 9 \text { ) }\end{array}$ & 1,890 & Subalpine dry: ohi'a (Metrosideros) forest \\
\hline $\begin{array}{l}\mathrm{Pu}^{\prime} \mathrm{u} \text { Wa'awa'a, Forest Bird Sanctuary (Melicope volcanica) } \\
\text { 20.iii.2002, J.G. Giffin (1 } \$ \text { ) }\end{array}$ & 1,710 & $\begin{array}{l}\text { Montane mesic: koa/'ohi'a } \\
\quad(\text { Acacia/Metrosideros) forest }\end{array}$ \\
\hline $\begin{array}{l}\text { Pu'u Wa'awa'a, Forest Bird Sanctuary (Myporum sandwicense) } \\
\left.\text { 30.iv.2003, J.G. Giffin (1 } \delta^{\star}\right)\end{array}$ & 1,735 & $\begin{array}{l}\text { Montane mesic: koa/'ohi' }{ }^{` a} \\
\text { (Acacia/Metrosideros) forest }\end{array}$ \\
\hline $\begin{array}{l}\mathrm{Pu}^{‘} \mathrm{u} \text { Wa'awa'a, Forest Bird Sanctuary (Ilex anomala) } \\
\text { 14.iv.2002, J.G. Giffin }\left(1 \delta^{\star}\right)\end{array}$ & 1,710 & $\begin{array}{l}\text { Montane mesic: koa/`ohi'a } \\
\quad \text { (Acacia/Metrosideros) forest }\end{array}$ \\
\hline $\begin{array}{l}\mathrm{Pu}^{‘} \mathrm{u} \text { Wa'awa'a, Forest Bird Sanctuary (Metrosideros polymorpha) } \\
\text { 14.vii.2002, J.G. Giffin }(1 \overbrace{}^{\star})\end{array}$ & 1,735 & $\begin{array}{l}\text { Montane mesic: koa/`ohi'a } \\
\quad(\text { Acacia/Metrosideros) forest }\end{array}$ \\
\hline $\begin{array}{l}\text { Kapapala Forest Reserve, 'Ainapo Trail, Halewai cabin (Vaccinium sp.) } \\
\text { 4.v.2001, J.G. Giffin (1 } \$ \text { ) }\end{array}$ & 2,360 & Subalpine dry: ohi'a (Metrosideros) forest \\
\hline $\begin{array}{l}\text { Mauna Loa F.R., Radio Relay Road (Geranium cuneatum) } \\
\text { 11.viii.2002, J.G. Giffin }(10)\end{array}$ & 2,070 & Subalpine dry: ohi`a (Metrosideros) forest \\
\hline
\end{tabular}

${ }^{1}$ A female specimen (paratype, same data) is in the Bishop Museum.

${ }^{2} \mathrm{~A}$ male (lab-reared from one of the females) was examined. The terminalia were measured, but not the wings or other body characteristics.

${ }^{3}$ Additional specimens. Bishop Museum: Kilauea (vii.1895, vii.1906, R.C.L. Perkins; 12.vii.1985, light trap, J.W. Beardsley); Maulua, forest above Honoka'a, 731 m (10.i.1977, S.L. Montgomery); “Ola'a, 29 mi” (vii.1927, W.M. Giffard); Pua Akala, nr. Hakalau Nat. Wildlife Ref., E Slope Mauna Kea (3.xi.1991, 1.xii.1991, R. Peck). Cornell University Insect Collection: Kohala Mts., Pu'u Pohoulaula, mossy 'ohi'a, 1,355 m (12.x.1997, J.K. Liebherr), ridge SE Pu'u Pohoulaula, mossy 'ohi'a, 1,180 m (12.x.1997, J.K. Liebherr); Upper Waiakea Forest Reserve, Kipuka Ainahou, Pu'u O`o trail, 1,737 m (24.v.1989, A.J. \& C.A. Tauber). Tauber Research Collection: Upper Waiakea Forest Reserve, Kipuka Ainahou, 1,737 m [7.vii.2001, J.G. Giffin; 26.x.1996, M.J. \& C.A. Tauber (Lot 96:55)]; South Hilo District, Kipuka 9 (near Mawae), 1,554 m [9.v.1997, M.J. \& C.A. Tauber (Lot 97:10); 14.x.1998, M.J. \& C.A. Tauber (Lot 98:34); Hilo Watershed, Pu‘u O`o Ranch Boundary, 1,600 m (2.vii.1999, J.G. Giffin).

The Hawaiian Micromus lineage provides an enticing opportunity for exploring the evolution of flightlessness, but it also presents difficulties. All five flightless Hawaiian species occur in areas that are not easily accessed; consequently, they are rarely collected and few specimens exist in museums. Virtually no published biological notes are available on the group. The larvae of only two Hawaiian Micromus species (both macropterous) have been described (Tauber \& Krakauer, 1997). Moreover, the subfamily Microminae has not been the subject of species-level cladistic analysis; thus, a phylogenetic context is unavailable for interpreting comparative studies (see Wagner \& Liebherr, 1992 for the significance of such data).

During the last decade, we (MJT, CAT) were fortunate to collect living specimens (two fecund females) and sub- sequently rear the larvae of Micromus usingeri (Zimmerman), the only flightless species known from the Island of Hawai' $i$, the largest and youngest island in the archipelago. Also, we (JGG) collected several additional adult specimens on Hawai' $i$ that appear to be intermediate between the flightless $M$. usingeri and the fully macropterous, flight-capable $M$. longispinosus (Perkins).

Other than the original descriptions (Perkins, 1899; Zimmerman, 1940) and Zimmerman's (1957) taxonomic treatment of the Hawaiian lacewings, virtually nothing has been published on either $M$. usingeri or M. longispinosus. The discovery of intermediate specimens indicated to us that the two species, which were previously not suspected of being related, may indeed be very close phylogenetically. Moreover, the intermediates provide a fine 
$\mathrm{T}_{\mathrm{ABLE}}$ 2. Assessment of the linear relationship between hindwing brachyptery (as measured by the ratio of the forewing and hind wing lengths) and attributes of the forewings and hind wings (M. longispinosus, M. usingeri and intermediates; $\mathrm{N}=21$ specimens/attribute; data from Appendices 1, 2).

\begin{tabular}{|c|c|}
\hline Wing attribute & Relationship \\
\hline Forewing length & $\mathrm{y}=6.853-0.554 \mathrm{x}(\mathrm{R}=-0.708, \mathrm{P}=0.0003)$ \\
\hline Forewing width & $\mathrm{y}=2.760-0.195 \mathrm{x}(\mathrm{R}=-0.748, \mathrm{P}<0.0001)$ \\
\hline Ratio of forewing length : width & $\mathrm{y}=2.481-0.040 \mathrm{x}(\mathrm{R}=-0.442, \mathrm{P}=0.0446)$ \\
\hline Hind wing length & $\mathrm{y}=6.329-0.970 \mathrm{x}(\mathrm{R}=-0.823, \mathrm{P}<0.0001)$ \\
\hline Hind wing width & $\mathrm{y}=2.255-0.334 \mathrm{x}(\mathrm{R}=-0.775, \mathrm{P}<0.0001)$ \\
\hline Ratio of hind wing length : width & $\mathrm{y}=3.106-0.166 \mathrm{x}(\mathrm{R}=-0.827, \mathrm{P}<0.0001)$ \\
\hline \multicolumn{2}{|l|}{ FOREWING SUBCOSTAL TRACE } \\
\hline Veinlets leaving Sc & $\mathrm{y}=20.738-0.412 \mathrm{x}(\mathrm{R}=-0.210, \mathrm{P}=0.3615)$ \\
\hline Veinlets reaching $\mathrm{C}$ & $\mathrm{y}=38.898-2.086 \mathrm{x}(\mathrm{R}=-0.632, \mathrm{P}=0.0021)$ \\
\hline sc-r crossveins & $\mathrm{y}=2.4622+0.995 \mathrm{x}(\mathrm{R}=0.496, \mathrm{P}=0.0222)$ \\
\hline \multicolumn{2}{|l|}{ FOREWING RADIAL TRACE } \\
\hline Branches (ORBS) leaving R & $\mathrm{y}=6.322+0.078 \mathrm{x}(\mathrm{R}=0.204, \mathrm{P}=0.3752)$ \\
\hline Branches after last ORB split & $\mathrm{y}=8.189+0.111 \mathrm{x}(\mathrm{R}=0.096, \mathrm{P}=0.6792)$ \\
\hline Veinlets on margin & $\mathrm{y}=30.010-1.030 \mathrm{x}(\mathrm{R}=-0.331, \mathrm{P}=0.1434)$ \\
\hline Intraradial crossveins & $\mathrm{y}=6.695+9.736 \mathrm{x}(\mathrm{R}=0.856, \mathrm{P}<0.0001)$ \\
\hline $\mathrm{r}-\mathrm{m}$ crossveins & $\mathrm{y}=2.537+0.563 \mathrm{x}(\mathrm{R}=0.634, \mathrm{P}=0.0020)$ \\
\hline \multicolumn{2}{|l|}{ FOREWING MEDIAL TRACE } \\
\hline Veinlets on margin & $\mathrm{y}=12.655-0.600 \mathrm{x}(\mathrm{R}=-0.547, \mathrm{P}=0.0102)$ \\
\hline Intramedian crossveins & $\mathrm{y}=3.984+1.508 \mathrm{x}(\mathrm{R}=0.608, \mathrm{P}=0.0035)$ \\
\hline m-cu crossveins & $\mathrm{y}=2.411+0.630 \mathrm{x}(\mathrm{R}=0.758, \mathrm{P}<0.0001)$ \\
\hline \multicolumn{2}{|l|}{ FOREWING CUBITAL TRACE } \\
\hline Veinlets on margin & $\mathrm{y}=11.896-0.546 \mathrm{x}(\mathrm{R}=-0.386, \mathrm{P}=0.0843)$ \\
\hline Intracubital crossveins & $\mathrm{y}=4.2624+0.174 \mathrm{x}(\mathrm{R}=0.147, \mathrm{P}=0.5258)$ \\
\hline cu-a crossveins & $\mathrm{y}=0.409+0.539 x(\mathrm{R}=0.765, \mathrm{P}<0.0001)$ \\
\hline \multicolumn{2}{|l|}{ FOREWING ANAL TRACE } \\
\hline Veinlets on margin & $\mathrm{y}=11.164-0.702 x(\mathrm{R}=-0.633, \mathrm{P}=0.0027)$ \\
\hline \multicolumn{2}{|c|}{ FOREWING VEINS: WIDTH/FOREWING WIDTH } \\
\hline $\mathrm{C}$ at $\mathrm{sc} 3$ & $\mathrm{y}=0.010864+0.002578 \mathrm{x}(\mathrm{R}=0.830, \mathrm{P}<0.0001)$ \\
\hline Sc at sc3 & $\mathrm{y}=0.011477+0.003470 \mathrm{x}(\mathrm{R}=0.877, \mathrm{P}<0.0001)$ \\
\hline $\mathrm{sc} 3$ & $\mathrm{y}=0.007833+0.00133 \times(\mathrm{R}=0.678, \mathrm{P}=0.0007)$ \\
\hline $\mathrm{R}$ at base of ORB1 & $\mathrm{y}=0.012256+0.002616 \mathrm{x}(\mathrm{R}=0.913, \mathrm{P}<0.0001)$ \\
\hline $\mathrm{R}$ at base of ORB3 & $\mathrm{y}=0.01103+0.002186 \mathrm{x}(\mathrm{R}=0.772, \mathrm{P}<0.0001)$ \\
\hline $\mathrm{R}$ at base of last $\mathrm{ORB}$ & $\mathrm{y}=0.010288+0.0024301 \times(\mathrm{R}=0.624, \mathrm{P}=0.0033)$ \\
\hline \multicolumn{2}{|l|}{ HIND WING SUBCOSTAL TRACE } \\
\hline Veinlets leaving Sc & $\mathrm{y}=26.390-4.345 \mathrm{x}(\mathrm{R}=-0.793, \mathrm{P}<0.0001)$ \\
\hline sc-r crossveins & $\mathrm{y}=0.722-0.131 \mathrm{x}(\mathrm{R}=-0.242, \mathrm{P}=0.2911)$ \\
\hline Sc and $R$ fused $(2=$ no; $1=$ yes $)$ & $\mathrm{y}=1.965-0.161 \mathrm{x}(\mathrm{R}=-0.772, \mathrm{P}<0.0001)$ \\
\hline \multicolumn{2}{|l|}{ HIND WING RADIAL TRACE } \\
\hline r-rs crossveins & $\mathrm{y}=4.846-0.857 \mathrm{x}(\mathrm{R}=-0.645, \mathrm{P}=0.0016)$ \\
\hline Intraradial crossveins & $\mathrm{y}=6.448-1.116 \mathrm{x}(\mathrm{R}=-0.657, \mathrm{P}=0.0012)$ \\
\hline Veinlets on margin & $\mathrm{y}=21.015-3.560 \times(\mathrm{R}=-0.758, \mathrm{P}<0.0001)$ \\
\hline $\mathrm{r}-\mathrm{m}$ crossveins & $\mathrm{y}=2.784-0.485 \mathrm{x}(\mathrm{R}=-0.704, \mathrm{P}=0.0004)$ \\
\hline \multicolumn{2}{|l|}{ HIND WING MEDIAL TRACE } \\
\hline Intramedial crossveins & $y=3.675-0.663 x(R=-0.567, P=0.0074)$ \\
\hline Veinlets on margin & $\mathrm{y}=16.606-2.8345 \mathrm{x}(\mathrm{R}=-0.700, \mathrm{P}=0.0004)$ \\
\hline m-cu crossveins & $\mathrm{y}=1.950-0.329 x(\mathrm{R}=-0.790, \mathrm{P}<0.0001)$ \\
\hline \multicolumn{2}{|l|}{ HIND WING CUBITAL TRACE } \\
\hline Intracubital crossveins & $\mathrm{y}=1.618-0.293 \mathrm{x}(\mathrm{R}=-0.588, \mathrm{P}=0.0050)$ \\
\hline Veinlets on margin & $\mathrm{y}=10.069-1.657 \mathrm{x}(\mathrm{R}=-0.821, \mathrm{P}<0.0001)$ \\
\hline cu-a crossveins & $\mathrm{y}=1.246-0.223 \times(\mathrm{R}=-0.599, \mathrm{P}=0.0041)$ \\
\hline \multicolumn{2}{|l|}{ HIND WING ANAL TRACE } \\
\hline Veinlets on margin & $\mathrm{y}=7.477-1.228 \mathrm{x}(\mathrm{R}=-0.813, \mathrm{P}<0.0001)$ \\
\hline
\end{tabular}

Abbreviations: a - anal; $\mathrm{C}$ - costa; cu - cubital; $\mathrm{m}$ - media; ORB - oblique radial branch; $\mathrm{R}, \mathrm{r}$ - radius; rs - radial sector; Sc, sc subcosta; sc 3 - third veinlet from subcosta to costa.

opportunity for comparative studies that explore the evolution of $M$. usingeri flightlessness.

Here, we offer comparative natural history information. Specifically, we (a) assess the variation in wing characteristics and body size of the macropterous, intermediate and brachypterous specimens, (b) compare the larvae of $M$. usingeri and M. longispinosus, and (c) provide notes on the egg size and developmental times of the two species. Finally, we (d) discuss our data in relation to the evolution of flightlessness in M. usingeri. 
TABLE 3. Assessment of the linear relationship between hindwing brachyptery (as measured by the ratio of the forewing and hind wing lengths) and attributes of the adult body (M. longispinosus, M. usingeri and intermediates; $\mathrm{N}=21$ specimens/attribute; data from Appendix 3).

\begin{tabular}{ll}
\hline Body attribute & Relationship \\
\hline Head, width & $\mathrm{y}=0.92715-0.000551 \mathrm{x}(\mathrm{R}=-0.020, \mathrm{P}=0.9317)$ \\
Eye, width & $\mathrm{y}=0.15684-0.001898 \mathrm{x}(\mathrm{R}=-0.242, \mathrm{P}=0.2909)$ \\
Vertex, width & $\mathrm{y}=0.60719+0.005314 \mathrm{x}(\mathrm{R}=0.293, \mathrm{P}=0.1880)$ \\
Frons, length & $\mathrm{y}=0.42520-0.008780 \mathrm{x}(\mathrm{R}=-0.471, \mathrm{P}=0.0313)$ \\
Gena, length & $\mathrm{y}=0.36704-0.000889 \mathrm{x}(\mathrm{R}=-0.060, \mathrm{P}=0.7961)$ \\
Gena, width & $\mathrm{y}=0.28126-0.000851 \mathrm{x}(\mathrm{R}=-0.046, \mathrm{P}=0.8433)$ \\
Antenna, length & $\mathrm{y}=6.56080-0.301700 \mathrm{x}(\mathrm{R}=-0.647, \mathrm{P}=0.00154)$ \\
Prothorax, length & $\mathrm{y}=0.43155+0.009665 \mathrm{x}(\mathrm{R}=0.468, \mathrm{P}=0.03220)$ \\
Prothorax, width & $\mathrm{y}=0.77845-0.011497 \mathrm{x}(\mathrm{R}=-0.429, \mathrm{P}=0.05249)$ \\
Mesothorax, length & $\mathrm{y}=0.75123-0.027588 \mathrm{x}(\mathrm{R}=-0.514, \mathrm{P}=0.01722)$ \\
Mesothorax, width & $\mathrm{y}=1.09860-0.028211 \mathrm{x}(\mathrm{R}=-0.443, \mathrm{P}=0.04446)$ \\
Mesotibia, length & $\mathrm{y}=1.13090-0.034408 \mathrm{x}(\mathrm{R}=-0.442, \mathrm{P}=0.05838)$ \\
Metatibia, length & $\mathrm{y}=2.06140-0.133400 \mathrm{x}(\mathrm{R}=-0.770, \mathrm{P}<0.0001)$ \\
Metafemur, length & $\mathrm{y}=1.21940-0.017727 \mathrm{x}(\mathrm{R}=-0.246, \mathrm{P}=0.2828)$ \\
\hline
\end{tabular}

\section{MATERIAL AND METHODS}

\section{Specimens and general methods}

We studied M. longispinosus and M. usingeri from 14 localities on the Island of Hawai'i (Table 1). A total of seven adult $M$. usingeri specimens are known from collections, worldwide: the six that we studied and a female (the paratype) in the Bishop Museum (Table 1). We did not use the lab-reared male in our wing or body measurements; however, because of the small number of male specimens, we dissected and included its terminalia. All specimens are deposited in the insect collections at the Bishop Museum, Honolulu, and Cornell University, Ithaca (Lot 1158). All measurements (except on the eggs) were made with NIH ImageJ software (http://rsb.info.nih.gov/ij/).

\section{Adult size and wing morphology}

One wing of each pair was removed from each specimen, mounted in glycerin on a slide, photographed and measured. The measurements were subjected to ANOVA (Appendices 1, 2 ) and tested for a correlation with the degree of hind-wing reduction (defined by the ratio, forewing length : hind-wing length) (Table 2). Adult body size and morphology were measured (as noted in Appendices 3, 4) using alcohol-preserved and pinned specimens. Male and female terminalia were cleared and mounted in glycerin on slides. See Figs 17 and 18 in Oswald (1993) for terminology. Eye width is the average of the left and right eyes.

\section{Egg and larval size}

Eggs were measured with an ocular micrometer one day after oviposition. The volume of the egg, which approximates a prolate spheroid, was calculated with the formula $\mathrm{V}=\pi / 6\left(\mathrm{LW}^{2}\right)$, where $\mathrm{L}$ is egg length and $\mathrm{W}$ is egg width as per Tauber et al. (1991). Measurements of larvae were made on fully fed first and third instars that had been killed in KAAD solution (see Stehr, 1987) and preserved in ethyl alcohol (see Tauber \& Krakauer, 1997). We tested for interspecific differences with the Student t-test (Appendices 5, 6).

\section{Life history}

Rearing procedures followed those of Tauber \& Krakauer (1997). Both larvae and adults received green peach aphids, Myzus persicae (Sulzer), as prey.

In our past experience, laboratory rearing of Hawaiian Micromus species from relatively high elevations is problematic; mortality rates are usually very high. Our best results have been obtained under relatively low temperatures.
Thus, we reared M. usingeri and M. longispinosus under three low-temperature regimens: (a) constant $15.8^{\circ} \mathrm{C}$, (b) fluctuating $18.3: 15.8^{\circ} \mathrm{C}$, and (c) fluctuating $21.1: 18.3^{\circ} \mathrm{C}$ (all $\pm 1^{\circ} \mathrm{C}$ ). The photoperiod was $16 \mathrm{~L}: 8 \mathrm{D}$; in regimens with a temperature cycle, the higher temperature occurred during the photophase. We recorded oviposition, egg hatch, larval moults, cocoon spinning, adult emergence, and death (Table 4). As expected, survival rates under all conditions were relatively poor, and because of low numbers, we did not apply statistical tests to the developmental or reproductive data.

\section{RESULTS}

Collection records to date [our own, those from specimens in the Bishop Museum and the Cornell University Insect Collection, and in the literature (Zimmerman, 1957)] indicate that both M. usingeri and the fully macropterous $M$. longispinosus have relatively broad distributions on the Island of Hawai' $i$, but that each is restricted altitudinally. Macropterous $M$. longispinosus have been collected in the Ka'u Puna, North and South Hilo, Hamakua and South Kona districts, at elevations between 1,200 and $1,800 \mathrm{~m}$, in montane wet or montane mesic forest habitats of Metrosideros, Cibotium, and Acacia (Table 1). The seven brachypterous M. usingeri were taken in the North Hilo, Hamakua and North Kona districts, at high altitudes (above 1,900 m), and in subalpine, dry forest habitats of Sophora and Metrosideros.

Intermediate specimens were collected in the districts of Ka'u, North Hilo, and North Kona in a variety of habitats, and generally at elevations between those of $M$. usingeri and the macropterous $M$. longispinosus $(1,700-2,400 \mathrm{~m})$ (Table 1). Hind-wing length on all of our specimens is significantly correlated with altitude $(\mathrm{y}=$ $15.18-0.0019 x ; R=0.778 ; \mathrm{P}<0.0001)$ and habitat type.

\section{Adult morphology}

Wing size, shape \& color

With the ratio of forewing length : hind-wing length as the standard, our specimens fall into three discrete groups, with M. longispinosus and M. usingeri occupying the two extremes (Fig. 1, Appendix 2). In the fully macropterous $M$. longispinosus $(\mathrm{N}=9 ; 5$ females, 4 males; 
TABLE 4. Life-history characteristics. Mean $\pm \mathrm{SD}(\mathrm{N}) . \mathrm{P}=$ temperature during photophase $(16 \mathrm{~h} / \mathrm{d}): \mathrm{S}=$ temperature during scotophase $(8 \mathrm{~h} / \mathrm{d})$. See Table 1 for information on the collection sites.

\begin{tabular}{|c|c|c|c|}
\hline \multirow{2}{*}{ Collection site } & \multicolumn{2}{|c|}{ Micromus longispinosus } & \multirow{2}{*}{$\frac{\text { Micromus usingeri }}{\mathrm{Pu}^{\prime} \mathrm{u} \mathrm{Wa}^{\prime} \mathrm{awa} \mathrm{a}, \mathrm{a}, 1,920 \mathrm{~m}}$} \\
\hline & Kipuka Ainahou, 1,737 m & Kipuka 9, 1,554 m & \\
\hline \multicolumn{4}{|l|}{ EGG SIZE, mm } \\
\hline Length & $0.769 \pm 0.052(7)$ & $0.828 \pm 0.033(12)$ & $0.866 \pm 0.035(10)$ \\
\hline Min-Max & $0.728-0.832$ & $0.780-0.844$ & $0.832-0.910$ \\
\hline Width & $0.353 \pm 0.014(7)$ & $0.368 \pm 0.024(12)$ & $0.364 \pm 0.021(10)$ \\
\hline Min-Max & $0.338-0.364$ & $0.338-0.390$ & $0.338-0.390$ \\
\hline \multicolumn{4}{|c|}{ OVIPOSITION RATE (eggs/day, $\mathrm{N}=$ number of days) } \\
\hline $\mathrm{P}: \mathrm{S} 18.3^{\circ}: 15.8^{\circ} \mathrm{C}($ Female $\# 1)$ & - & $5.5 \pm 2.9(38)$ & $4.4 \pm 2.0(25)$ \\
\hline $\mathrm{P}: \mathrm{S} 18.3^{\circ}: 15.8^{\circ} \mathrm{C}($ Female \#2) & - & $2.8 \pm 2.2(12)$ & $4.6 \pm 1.5(36)$ \\
\hline Constant $15.8^{\circ} \mathrm{C}$ & - & $7.8 \pm 3.2(6)$ & - \\
\hline \multicolumn{4}{|c|}{ DEVELOPMENTAL TIME (days; P : S $21.1^{\circ}: 18.3^{\circ} \mathrm{C}$ ) } \\
\hline Egg & $8.4 \pm 1.0(19)$ & - & $8.5 \pm 0.5(14)$ \\
\hline $\mathrm{L} 1$ & $4.85 \pm 1.0(33)$ & - & $5.3 \pm 0.89(13)$ \\
\hline $\mathrm{L} 2$ & $5.1 \pm 0.8(16)$ & - & $5.5 \pm 0.6(6)$ \\
\hline L3 & $6.0 \pm 1.7(3)$ & - & $5(1)$ \\
\hline \multicolumn{4}{|c|}{ DEVELOPMENTAL TIME (days; $\mathrm{P}: \mathrm{S} 18.3: 15.8^{\circ} \mathrm{C}$ ) } \\
\hline Egg & - & $10.9 \pm 1.1(42)$ & $10.2 \pm 0.7(27)$ \\
\hline L1 & - & $5.4 \pm 0.7(34)$ & $5.4 \pm 0.9(18)$ \\
\hline $\mathrm{L} 2$ & - & $5.7 \pm 0.8(25)$ & $5.1 \pm 0.7(12)$ \\
\hline L3 & - & $5.1 \pm 0.6(17)$ & $6.5 \pm 1.0(12)$ \\
\hline Cocoon (prepupa + pupa) & - & $8,10(2)$ & $23(2)$ \\
\hline Total & - & $52(1)$ & $49,50(2)$ \\
\hline \multicolumn{4}{|c|}{ DEVELOPMENTAL TIME (days, constant $15.8^{\circ} \mathrm{C}$ ) } \\
\hline Egg & - & $12.9 \pm 0.3(26)$ & - \\
\hline L1 & - & $6.8 \pm 0.8(17)$ & - \\
\hline $\mathrm{L} 2$ & - & $5.8 \pm 0.5(5)$ & - \\
\hline L3 & - & $6.8 \pm 0.9(5)$ & - \\
\hline Cocoon (prepupa + pupa) & - & $30(2)$ & - \\
\hline Total & - & $61,62(2)$ & - \\
\hline
\end{tabular}

Note: The reduced numbers of individuals during rearing under all three thermal regimens do not indicate rates of mortality because specimens were removed during each instar for preservation.

Fig. 2; Appendices 1, 2), the forewings and hind wings are oblong and fully developed; the ratio of the forewing length to hind-wing length is approximately $1: 1$; individuals are capable of flying.

The M. longispinosus forewing is slightly more robust than the more membranous hind wing; it is also slightly convex; and it has three clear lines of flexion - the mediocubital, cubitoanal, and intraanal flexion lines of Oswald (1993). The costal flexion line is not discrete; in some specimens it appears only as a longitudinal streak through the costal area, but it does not show flex. In all specimens the costal area has a slight, concave depression. The radiomedial flexion line appears to be absent or very faint. The venation is largely longitudinal with varying numbers of transverse crossveins (Appendix 1); the veins are rounded, unthickened and somewhat darker than the surrounding membrane.

At the other extreme is the flightless $M$. usingeri $(\mathrm{N}=$ 6; 4 females, 2 males). These individuals have forewings that are considerably smaller than those of M. longispinosus, and their hind wings are reduced to small triangular lobes (Fig. 3; Appendices 1, 2). The ratio of their forewing to hind-wing length is approximately $6: 1$.

In general, $M$. usingeri forewings appear elytra-like. The foreshortened forewing is oblong to obovate in shape; it has a coriaceous, rigid, convex surface; lines of flexion are absent; the veins are flat and wide; and the venation appears reticulate rather than primarily linear. The entire wing, including the veins, has an amber color.

The seven intermediate specimens $(\mathrm{N}=7 ; 3$ females, 4 males) are characterized by forewings that are slightly reduced and slightly coriaceous, and hind wings that are considerably diminished and that have rounded to angulate distal margins (Fig. 4; Appendices 1, 2). The ratio of the forewing : hind-wing length averages approximately $2: 1$. These adults appear to be incapable of flight; captured specimens that had considerable opportunity to fly neither opened their wings, nor attempted to fly (JGG, personal observation).

The silhouette of both the forewing and the hind wing varies considerably among the intermediate individuals, as do most of the venational and other characteristics (e.g., lines of flexion, sclerotization of the wing membrane and veins, branching of veins) that distinguish $M$. usingeri from macropterous $M$. longispinosus. In most traits, the variation falls between the two extremes and is correlated with the degree of hind-wing reduction (Figs 2-4; Table 2; Appendices 1, 2).

Wing venation

At first glance, the forewing venation of $M$. usingeri and M. longispinosus appears markedly divergent (Figs 2, 3 ). However, closer observation shows that only some aspects of the venation vary; others are conserved. 


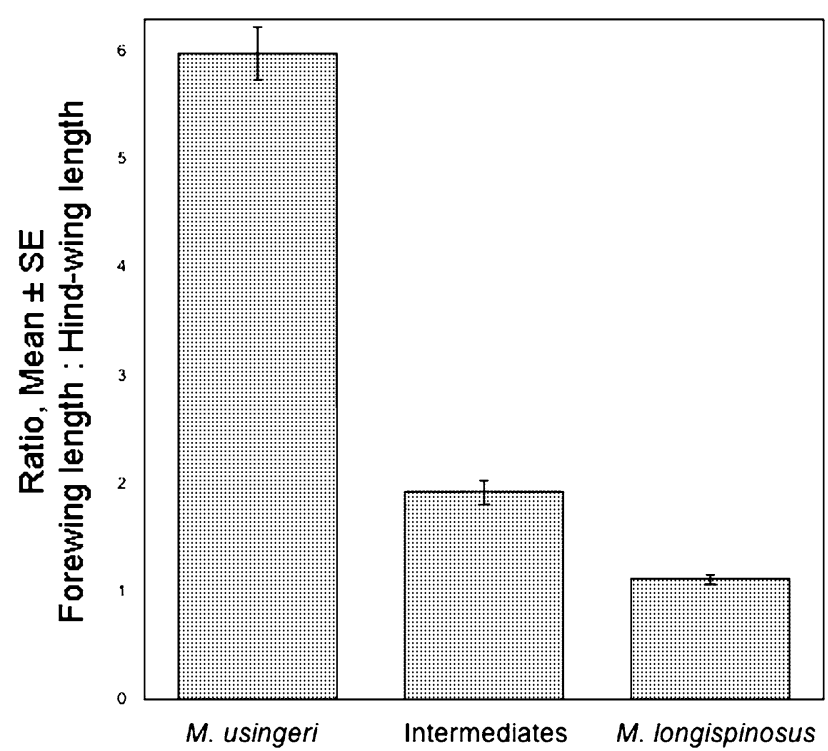

Fig. 1. Hind-wing reduction in three groups of Micromus lacewings from the Island of Hawai' $i$.

In general, the major longitudinal veins of the forewing show little variation in their branching patterns (Appendix 1). Moreover, the small amount of variation that does occur in the longitudinal veins is not significantly correlated with the degree of hind-wing reduction (Table 2). For example, in the radial trace, the number of oblique radial branches (ORBs) and the number of times each ORB splits do not vary significantly among our specimens. Although the number of veinlets reaching the radial margin differs between $M$. usingeri and the macropterous $M$. longispinosus, the variation in this trait is not significantly correlated with the extent of hind-wing reduction (Table 4).

A similar stable pattern prevails for the branching patterns of other major veins on the forewings. For example, the media (M) consistently has two deep splits that yield three sub-traces (M1, M2, and M3); after the first split, the second split occurs in either the upper or lower major branch apparently unrelated to hind-wing reduction. The cubitus has one major division near the base of the wing, followed by subsequent forking that results in three to four relatively long longitudinal branches. The branching pattern of these veins also does not appear to correlate with hind-wing reduction. The anal vein has three major forks; each fork is present on the wings of all specimens.

In contrast to the stability of the major longitudinal veins, other features of the forewing venation vary significantly with hind-wing reduction. Among our specimens, the number of crossveins, both within and between traces, is correlated positively with hind-wing reduction the only exception being the number of crossveins in the intracubital trace where very little variation is expressed (Table 2, Appendix 2). Notably, the trend in veinlets reaching the wing margin is the reverse of that in the crossveins; the number of terminal veinlets tends to drop as the degree of hind-wing brachyptery increases. Among our specimens, this relationship is significant in the sub-

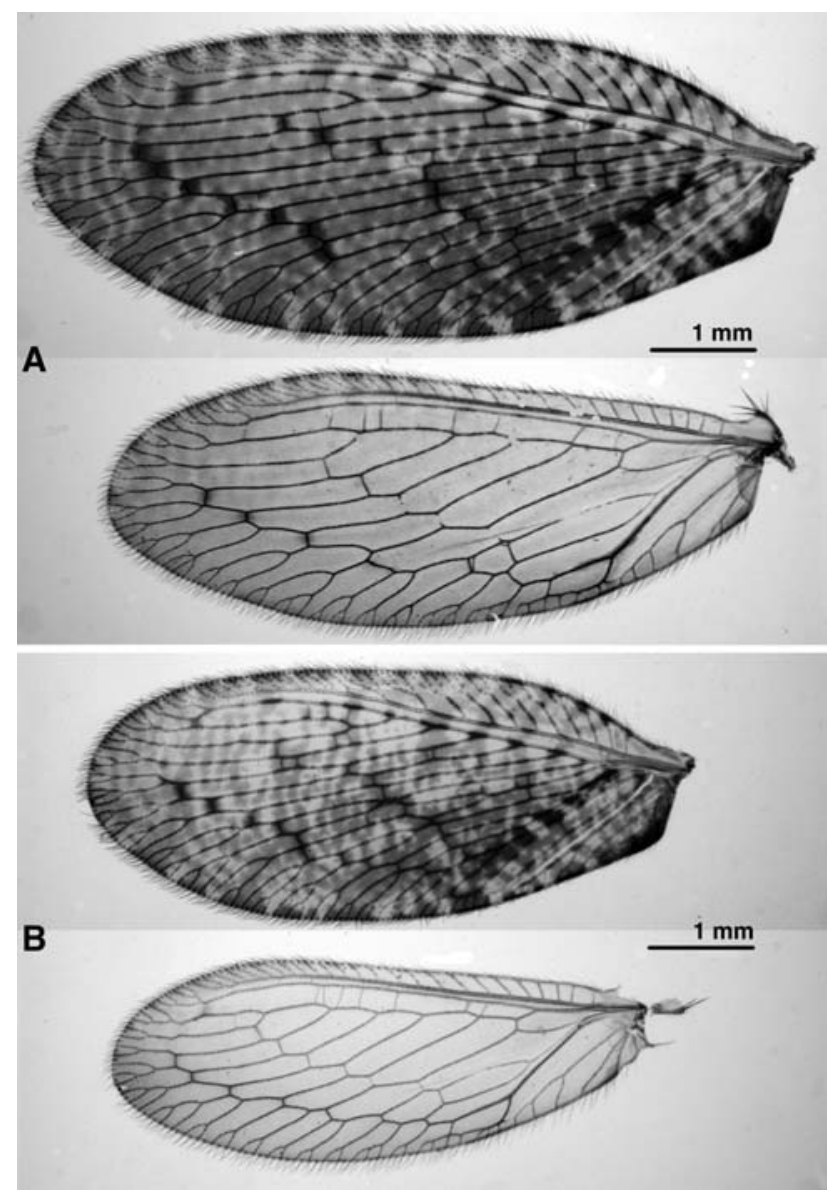

Fig. 2. Forewings and hind wings of two representative Micromus longispinosus specimens. A - Upper Waiakea Forest Reserve, Powerline Rd., Kipuka, 1765 m; B - Kapapala/Ka'u Forest Reserve, Koa Management Area, 1,560 m. See Oswald (1993) for names of veins.

costal, medial, and anal traces, but not in the radial or cubital (Table 2).

In addition to the characteristics above, the relative widths (vein width/forewing width) of all the forewing veins that we measured show significant positive correlation with hind-wing brachyptery (Table 2). Moreover, the actual widths of three of these veins vary significantly and positively with hind-wing reduction (data not shown).

Hind-wing venation shows a consistent pattern of change as the wings become reduced. Most notable is the fusion of the subcosta and radius, the loss of oblique radial branches, the fusion of M1 with the proximal radial fork, the loss of branching and crossveins, and the sclerotization of the subcosta and cubitus (cf., Figs 2, 3; Appendix 2).

\section{Body size}

With a few interesting exceptions, the body-size characteristics that we measured do not differ significantly among the fully winged, intermediate, and brachypterous groups (Appendix 3). On the head capsule, only the length of the frons has a very slight correlation with hindwing reduction; none of the other head measurements show any correlation (Table 3 ). Also, the sclerites of male 


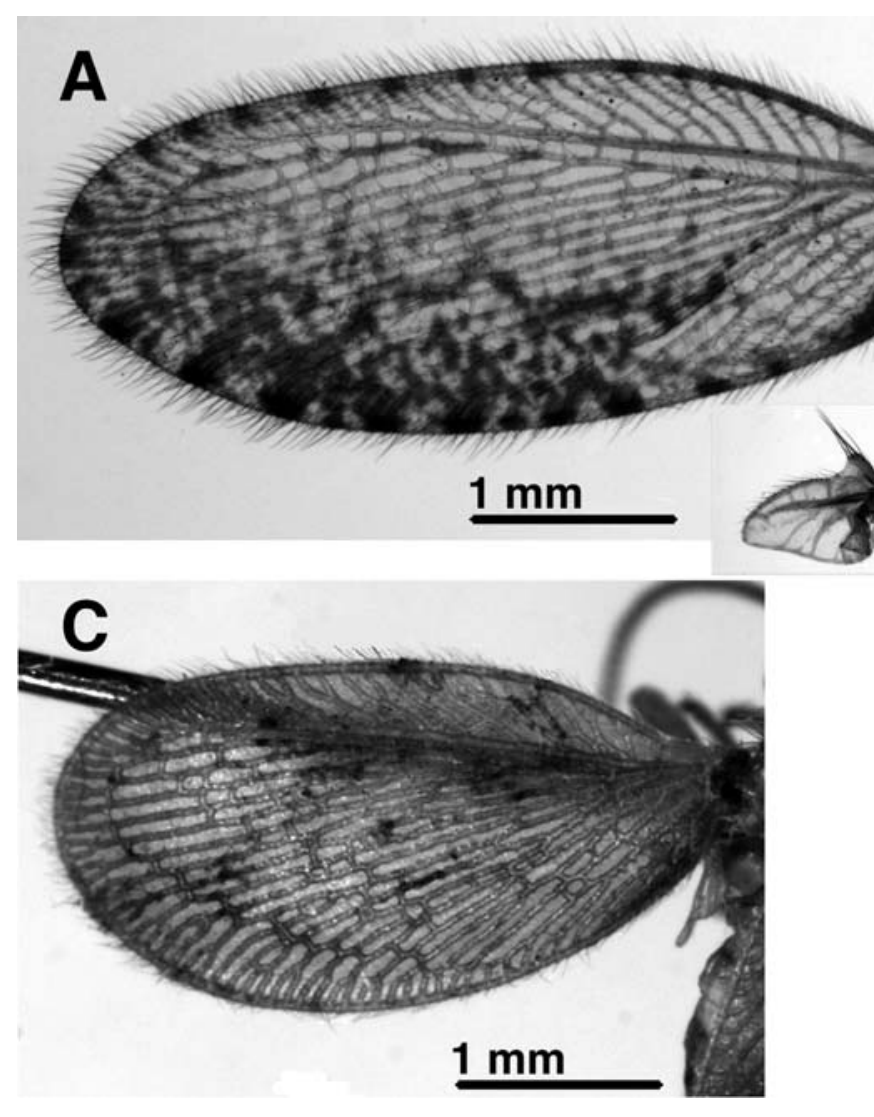

abdominal segments 8 and 9 show no significant differences in size between $M$. usingeri and M. longispinosus (Appendix 4). Prothoracic length, but not width, is negatively correlated with hind-wing brachyptery, and both the length and the width of the mesothorax are negatively correlated with reduction of the hind wings (Table 3 ). Both antennal length and the length of the metathoracic tibiae show a strong negative correlation with the degree of hind-wing brachyptery.

\section{Male terminalia}

M. longispinosus males have very distinctive abdominal characteristics that distinguish them from the males of all other Hawaiian Micromus species (Zimmerman, 1957). The unique feature for which the species was named - the long, lanceolate, spine-covered process on the posteroventral margin of the T9+ectoproct - is more than twice as long as the setose, digitiform process immediately dorsal to it (Fig. 5A). Internally, M. longispinosus males have a V-shaped gonarcus (dorsal view) with an elongate, smooth, ventrally curved mediuncus. In preserved specimens, the mediuncus usually does not protrude from the abdominal cavity. The parabaculum is robust and well sclerotized and the callus cerci are distinguishable.

A rounded T9+ectoproct and the shape of the two terminal processes are distinguishing features of the $M$. usingeri male terminalia (Fig. 5B). The process on the posteroventral margin of tergite 9 is narrow, lanceolate and spine-covered, as in M. longispinosus, but it is much shorter, its ventral margin is more arcuate, and its dorsal teeth are smaller (Appendix 4). In one of our two male specimens, some of the teeth are distributed over the

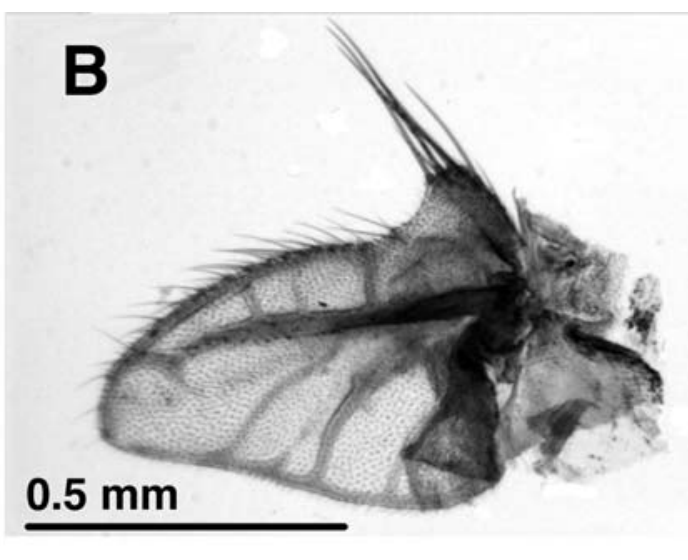

Fig. 3. Micromus usingeri wings. A - Mauna Kea Forest Reserve, Kaluamakani, 2,315 m; forewing and hind wing to

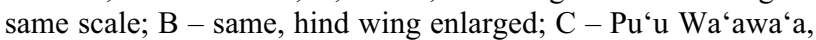
SSW of Kileo, 1,920 m. See Oswald (1993) for names of veins.

distal part of the lobe and others are grouped in a cluster mesally on the lobe. On the other male, the teeth occur more or less evenly along the length of the lobe. The $M$. usingeri terminalia also have smaller posterodorsal, digitiform processes, a smaller ratio between the lengths of the two terminal processes, very faint or indistinguishable callus cerci, and shorter terminal setae on the posterior margins of the tergites (Appendix 4).

As in $M$. longispinosus, the gonarcus (dorsal view) in our two M. usingeri male specimens is V-shaped. However, they differ from $M$. longispinosus in that the mediuncus protrudes from the abdomen (especially after the specimens were cleared and mounted in glycerin), and the parabaculum is somewhat foreshortened and weakly sclerotized (perhaps teneral on the lab-reared specimen). We did not dissect the internal organs from the holotype male and do not have other mature specimens, thus precluding detailed comparisons of the internal structures.

The only character on the male terminalia that differentiates the intermediate specimens from both the fully macropterous $M$. longispinosus and the brachypterous $M$. usingeri is the length of the lanceolate posteroventral process. The intermediates fall in a distinct grouping between the two species (Appendix 4). In most of the other characters on the terminal segment, including the callus cerci, the intermediate specimens are not significantly different from those of either M. longispinosus or $M$. usingeri. The notable exception is the length of the long terminal setae, where both $M$. longispinosus and the intermediates differ significantly from $M$. usingeri (Appendix 4). 


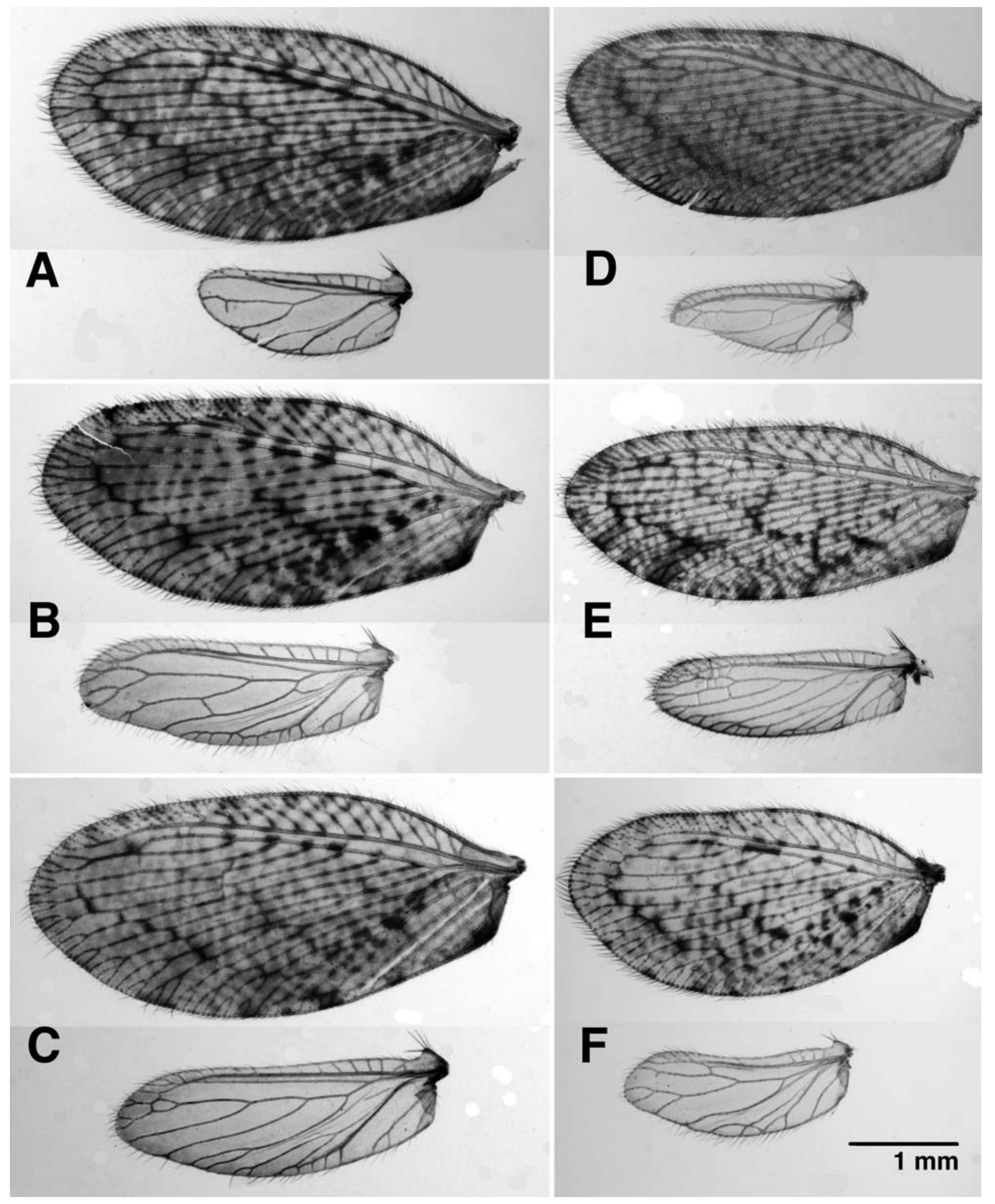

Fig. 4. Wings of intermediates between Micromus longispinosus and Micromus usingeri (all images to same scale). A, B, C, F Pu'u Wa'awa'a, Forest Bird Sanctuary, 1,890 m; D - Mauna Loa Forest Reserve, Radio Relay Road, 2,070 m; E - Kapapala F. R., 'Ainapo Trail, Halewai cabin, 2,360 m. See Oswald (1993) for names of veins.

\section{Life-history characteristics}

Developmental time

At the higher of the two fluctuating-temperature regimens $\left(21.1: 18.3^{\circ} \mathrm{C}\right)$, all larvae died before emerging from the cocoon, and the developmental times for $M$. usingeri and macropterous $M$. longispinosus appear similar (Table 4). Under the lower fluctuatingtemperature regimen $\left(18.3: 15.8^{\circ} \mathrm{C}\right)$, survival and devel- 

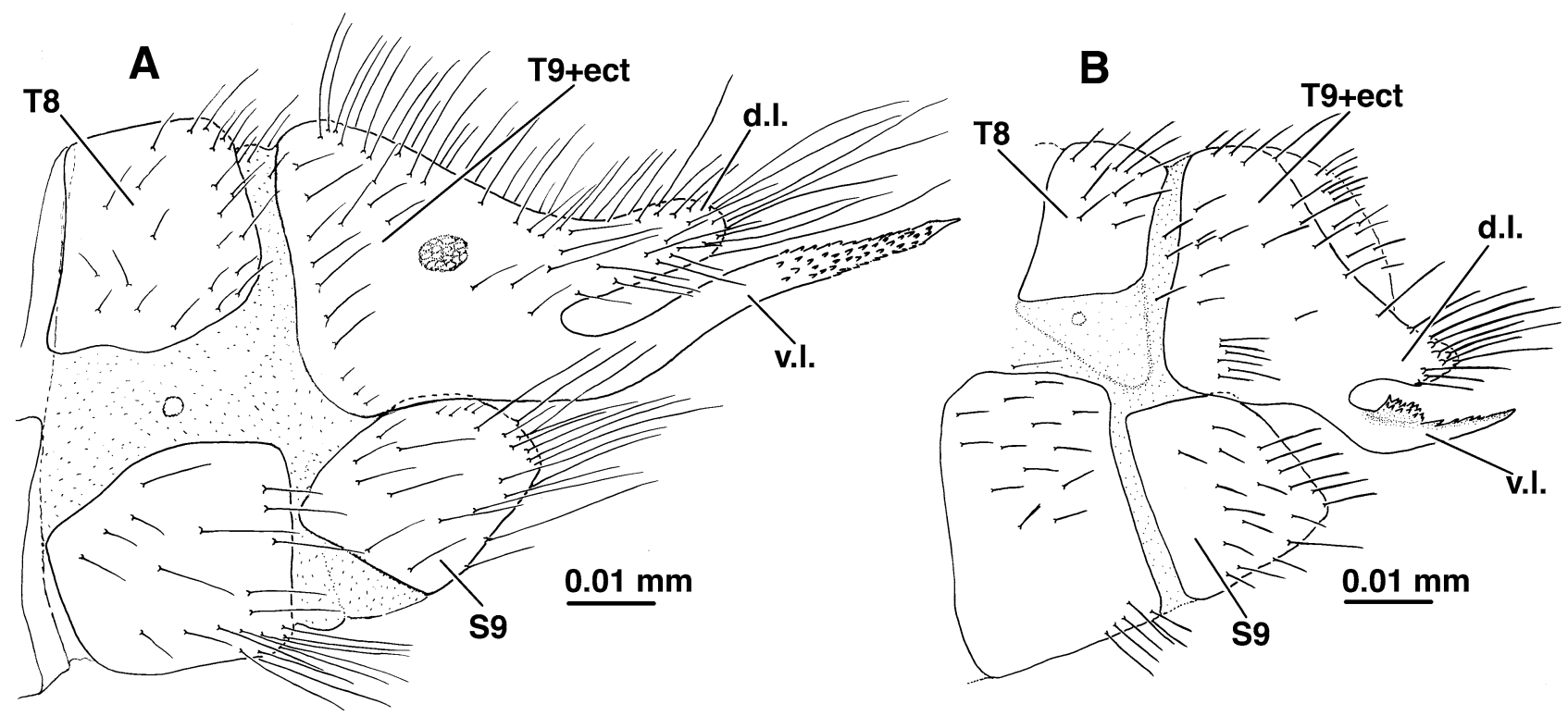

Fig. 5. Terminal segments of male abdomen, lateral view. A - Micromus longispinosus; B - Micromus usingeri. d.1. - dorsal lobe; S9 - ninth sternite; T8 - eighth tergite; T9+ect - ninth tergite plus ectoproct; v.l. - ventral lobe.

opmental rates, once again, seem not to differ between the two species. However, both species appeared to survive better but development was slightly slower than in the higher fluctuating-temperature regimen.

Only M. longispinosus was reared in a constant $15.8^{\circ} \mathrm{C}$ regimen. The survival rate at this temperature was similar to that under fluctuating $18.3: 15.8^{\circ} \mathrm{C}$, but development was slower. For example, complete development from oviposition to adult emergence took $\sim 10$ days longer under the constant low temperature than the fluctuating low temperature regimen (Table 4).

Egg size and oviposition rate

Although eggs from macropterous $M$. longispinosus females were significantly shorter than those of the $M$. usingeri females, neither egg width nor egg volume differed significantly between the two species (Table 4). Oviposition rates ranged from 2.8 to 5.5 eggs per day for three macropterous $M$. longispinosus females and from 4.4 to 4.6 eggs per day for two M. usingeri females (all under a fluctuating-temperature regimen of $\left.18.3: 15.8^{\circ} \mathrm{C}\right)$ (Table 4).

\section{Larvae}

Among the various features that we measured on fully-fed first and third (final) instars, only body length differed significantly between $M$. longispinosus and $M$. usingeri (Appendices 5, 6). All other aspects (head size and thoracic width, mandible and antennal length) did not.

\section{DISCUSSION}

Our findings indicate that brachyptery and flightlessness in M. usingeri is associated more with cooler, drier environments at high elevations, than the warmer, moister and more rainy, lower-elevation environments of its macropterous relative, M. longispinosus. Such a trend is not unusual for insect groups with flightless species and has been well documented in endemic Hawaiian lineages of Lygaeidae (Ashlock \& Gagné, 1983), Oecophoridae (Howarth, 1987), Dolichopodidae (Evenhuis, 1997), and Carabidae (Liebherr, 2000, 2006a).

\section{Origin of intermediates}

The fact that the intermediate specimens span the range of most character states that distinguish M. longispinosus and $M$. usingeri prompts several questions: (1) Do the intermediate specimens represent occasional hybridization events or a hybrid zone along the boundary between two distinct species ( $M$. longispinosus and M. usingeri)? For example, natural hybrids have been shown to occur between morphologically very distinct sister-species of Hawaiian Drosophila (Carson et al., 1989; see Bonacum et al., 2005). In the Drosophila case, the two species presumably diverged in allopatry; subsequently some populations became partially sympatric and remained reproductively isolated through sexual selection. Hybridization is believed to occur when populations become unusually small and the normal interspecific mate-choice system breaks down (Carson et al., 1989). A similar situation is possible with $M$. longispinosus and $M$. usingeri if the two species diverged allopatrically (presumably at high and low elevations) and occasionally hybridize at midelevations.

Alternatively, (2) do the intermediate specimens represent transitional (parapatric) populations in the on-going, perhaps repeated evolution of brachypterous, highelevation forms? And if so, are M. longispinosus and $M$. usingeri valid (reproductively isolated) species? Numerous examples of parapatric diversification are found within island and continental lineages of insects (e.g., Endler, 1977), and some very spectacular cases occur along the steep altitudinal and ecological transects of the two major volcanoes of the Island of Hawai' $i$ 
(Howarth, 1987; Liebherr, 2006b). The evolution of brachyptery in $M$. usingeri could constitute another such striking example of parapatric divergence resulting from adaptation to a gradient of extreme physical (or biological) conditions. Studies on the phylogeny of the Hawaiian Micromus lineage, the ecological characteristics of diverse geographic populations, and the genetic basis for specific morphological and life-history traits, would help answer the above questions. Meanwhile, we believe that it is prudent to maintain $M$. usingeri as a species separate from $M$. longispinosus and the intermediates, while recognizing that there probably is interspecific gene flow.

\section{Evolution of brachyptery: Sequential changes in wing morphology}

Using the variation in our specimens' wing size and structure as hints to possible transitional stages, we can propose a sequence of changes in wing morphology during the evolution of brachyptery in $M$. usingeri (whether allopatric or parapatric).

\section{Hind wing}

The striking changes leading to the brachypterous hind wing apparently began with a gradual diminution of the oblong membranous wing, followed by a narrowing of the distal margin until the tip became acute, and finally, the drastic reduction of the wing to a triangular stub. Also, as the hind wing decreased in size, several longitudinal veins (notably Sc and R) fused and became more heavily sclerotized; branches (e.g., those from Sc, R and $\mathrm{M})$ and crossveins were lost. The anterior margin of the wing, including the frenulum, remained relatively robust.

\section{Forewing}

The equally striking modifications of the forewing involved the transition from a flexible, membranous, oblong wing with primarily longitudinal venation, to a hardened, elytra-like wing structure with reticulate venation. Interestingly, as the transition occurred, the branching patterns of the major longitudinal veins remained largely unchanged. Branching was altered only on the margins of the subcostal, medial and anal traces, where its frequency appears to have decreased gradually. This change in branching was concomitant with a gradual increase in the convexity of the wing, loss of the lines of flexion, increase in the number of crossveins both within and between traces (all, except the cubital trace), widening of the veins, and sclerotization of the forewing throughout.

The above individual changes do not appear to be tightly linked in our specimens. For example, among our intermediate specimens, the forewings show disparate patterns of variation in wing size, crossvein numbers, terminal branching, and the degree of sclerotization. Moreover, in one of our M. usingeri specimens, which has the typical stub-like hindwings, the forewing silhouette is not rounded as in the other $M$. usingeri specimens, but elongate as in M. longispinosus (Fig. 3). These disparities may reflect complex, multigenic inheritance for brachyptery.

\section{Ecological correlates of brachyptery}

The morphology of the M. usingeri wings (marked foreshortening and sclerotization of the forewings, the shrinking of the hind wings to pad-like stubs) substantiates that the species is flightless; the intermediates also appear to be flightless. Our observations and numerous collections of $M$. longispinosus at lights show that both males and females of this species have the ability to fly; however, the range and frequency of their flight is unstudied. Nor is there any information on population structure or habitat fidelity for either of the species. Thus, it is unknown whether the evolution of brachyptery in $M$. usingeri is coincident with reduced dispersal (for discussions of this issue see Liebherr, 2000; Gillespie \& Roderick, 2002).

Habitat stability or permanence and habitat openness are often cited as explanations for the evolution of brachyptery and loss of flight (e.g., see reviews by Roff, 1990, Wagner \& Liebherr, 1992). However, at this time, the microhabitats of the two species are unknown, and there is no evidence that the habitats that M. longispinosus occupies at lower elevations are any less stable or more protected than those that $M$. usingeri inhabits at high elevations. Thus, the selective pressures for wing reduction and/or flightlessness in $M$. usingeri, as well as those for maintaining full-sized wing and flight in $M$. longispinosus, remain undefined.

We suggest that flightlessness in M. usingeri may be associated with low night-time temperatures in its highelevation range. Hemerobiid adults, including those of Micromus, generally fly only at dusk or at night; they rarely fly during the day unless disturbed. Night-time temperatures at high elevations typically are considerably lower than those at lower elevations (e.g, see discussion by Mani, 1962), and it is possible that the night-time temperatures where $M$. usingeri occurs rarely exceed the lower thermal threshold for flight. Thus, occupation of this habitat would render the maintenance of large, membranous wings and flight superfluous.

Such a scenario, however, would not explain the selective factors favoring the evolution of elytra-like forewings in $M$. usingeri. One hint may be found in an essay by J.B.S. Haldane (1927), where he emphasized that the surface tension of water can pose a serious hazard for insects. Although the physical and chemical properties of the elytra-like forewings are unstudied, it is not unreasonable to imagine that their convex, heavily coriaceous (rigid) surfaces may have evolved as an adaptation to avoid being entrapped by water in moist mossy or leafy interstices. Such a hypothesis would be supported if it were shown that the beetle-like, brachypterous $M$. usingeri adults occur in a more confined, moist microhabitat than that of membranous-winged $M$. longispinosus. Such a shift in microhabitat is not unreasonable to expect; brachypterous Hawaiian carabid beetles are frequently associated with confined, moist moss-mat habitats (Liebherr \& Short, 2006). However, other crucial advantages for having coriaceous wings (e.g., defense 
against natural enemies or abrasion) are possible and deserve consideration.

\section{Life-history correlates of brachyptery}

Wing reduction and the loss of flight frequently are associated with marked trade-offs in body size and other life-history characteristics that have profound ecological and evolutionary consequences. Examples of such changes are summarized in various reviews (e.g., Roff, 1990; Wagner \& Liebherr, 1992; Zera \& Harshman, 2001) and are well-documented in Hawaiian Carabidae (Liebherr, 2000, 2007). In $M$. longispinosus and $M$. usingeri some body-size changes are correlated with brachyptery; however, we found very few life-history traits that differ between the species, and most of those are subtle, as described below.

\section{Adult size}

Hind-wing brachyptery is associated with a very small decrease in the length of the frons and relatively large decreases in the the size of the mesothorax (length, 24\%; width $\sim 17 \%)$ and the lengths of the antennae $(\sim 28 \%)$ and metatibiae $(\sim 39 \%)$ (Table 3$)$. Reduction in the thorax of flightless insects is not unexpected; it is reported for numerous brachypterous species and probably reflects the redirection of reserves from flight muscles and skeletal structure to other functions (e.g., Zera \& Denno, 1997; Zera \& Harshman, 2001). Analogous reasoning could be applied to the shortened antennae and metatarsi. Reduced antennal length could be coincident with a reduced requirement for sensory information in the flightless adult. Because neither $M$. longispinosus nor $M$. usingeri was observed to jump, we propose that foreshortened metatarsi could reflect a lost take-off or landing function in the flightless $M$. usingeri.

\section{Life-history and larval traits}

In general, the life-history traits that we recorded (egg size, oviposition rate, larval developmental rates and response to temperature) appear not to differ between $M$. longispinosus and M. usingeri. Moreover, our measurements of the length and width of larval head capsules and thoracic segments, as well as the length of the mandibles and the antennae, show no significant differences between the two species in either instar. The only measurement differing significantly between $M$. longispinosus and M. usingeri is the overall size (as measured by the length) of fully-fed first and third instars, with M. longispinosus being the larger in both instars.

Taken altogether, the above pattern of variation leads us to several conclusions. First, in view of the similarly sized adult head capsules, larval head capsules and larval mandibles of the two species, we suspect that the evolution of brachyptery in M. usingeri was not associated with a major change in either adult or larval prey. Second, although $M$. longispinosus larvae may achieve greater body mass than do $M$. usingeri larvae, M. usingeri larvae are able to produce full-sized adults, but with foreshortened forewings and vestigal hind wings. Whatever the selective advantage of reduced wing size (if any), this developmental trade-off may have helped M. usingeri to expand its range into the more rigorous subalpine environment by reducing the larval resources required to produce adults that maintain a relatively high oviposition rate, full-sized eggs, and larvae with full-sized head capsules and mouthparts.

\section{Additional taxonomic consideration}

M. longispinosus and M. usingeri forewings exhibit an interesting exception to the characteristic branching pattern in micromine hemerobiids. In the Microminae, the most proximal fork of the most proximal radial sector is located within the distal two thirds of the posterior sectoral trace (Oswald, 1993). However, this character state does not occur in any of our five $M$. usingeri specimens; it is present in only two of the seven intermediates, and notably, in only three of the nine fully winged $M$. longispinosus specimens. These data provide another example, among many, of a Hawaiian species expressing a degree of variation that exceeds the range of variation in its continental congeners (e.g., Zimmerman, 1970; Montgomery, 1982; Gillespie, 1992; Howarth \& Mull, 1992; Otte, 1994; Rubinoff \& Haines, 2005; Tauber \& Krakauer, 1997).

ACKNOWLEDGEMENTS. It is a pleasure to acknowledge the help and advice that K.Y. Kaneshiro (University of Hawai'i) extended to us. We greatly appreciate the comments from J.K. Liebherr and K. Magnacca. The following extended muchappreciated cooperation during various phases of the study: W.D. Duckworth, N.L. Evenhuis, C.P. Ewing, B.H. Gagné, R.G. Gillespie, B. Gollands, F.G. Howarth, S.E. Lew, J.K. Liebherr, S.E. Miller, S.P. Myers, A. Seago, C.P. Stone, W. Stormont, A.J. Tauber, M.J. Tauber, P.J. Tauber, S.B. Tauber (deceased), and K.W. Will. We also thank L.E. Ehler and the Department of Entomology, Davis, for their cooperation. The work was supported in part by the National Science Foundation (BSR8817822, DEB 0542373), the National Geographic Society, NRI-USDA Competitive Grants 9802447 and 200235316-1231, Regional Project W-1185, and Cornell University.

\section{REFERENCES}

Ashlock P.D. \& Gagné W.C. 1983: A remarkable new micropterous Nysius species from the eolian zone of Mauna Kea, Hawaii Island (Hemiptera: Heteroptera: Lygaeidae). Int. J. Entomol. 25: 47-55.

Bonacum J., O’Grady P.M., Kambysellis M. \& Desalle R. 2005: Phylogeny and age of diversification of the planitibia species group of the Hawaiian Drosophila. Mol. Phylogen. Evol. 37: 73-82.

Carlquist S. 1980: Hawaii, a Natural History. 2nd ed. Pacific Tropical Botanical Garden, Lawai, Kauai, Hawaii, 468 pp.

Carson H.L., Kaneshiro K.Y. \& Val F.C. 1989: Natural hybridization between the sympatric Hawaiian species Drosophila silvestris and Drosophila heteroneura. Evolution 43: 190-203.

EndLer J.A. 1977: Geographic Variation, Speciation, and Clines. Princenton University Press, Princenton, 246 pp.

Evenhuis N.L. 1997: Review of flightless Dolichopodidae (Diptera) in the Hawaiian Islands. Bishop Mus. Occ. Pap. 53: $1-30$.

GILLESPIE R.G. 1992: Impaled prey. Nature 355: 212-213.

Gillespie R.G. \& Roderick G.K. 2002: Arthropods on islands: colonization, speciation, and conservation. Annu. Rev. Entomol. 47: 595-632. 
Haldane J.B.S. 1927: On being the right size. In Maynard Smith J. (ed.): On Being the Right Size and Other Essays. Oxford University Press, Oxford, pp. 1-8.

HowARTH F.G. 1987: Evolutionary ecology of aeolian and subterranean habitats in Hawaii. Trends Ecol. Evol. 2: 220-223.

Howarth F.G. \& Mull W.P. 1992: Hawaiian Insects and their Kin. University of Hawaii Press, Honolulu, $160 \mathrm{pp}$.

LIEBHERR J.K. 2000: The unity of characters: ecological and morphological specialization in larvae of Hawaiian platynine Carabidae (Coleoptera). Invertebr. Taxon. 14: 931-940.

LieBHERR J.K. 2006a: Hawaiian Blackburnia beetles (Coleoptera, Carabidae, Platynini): patterns of specialization with implications for conservation. Mitt. Dt. Ges. Allg. Angew. Entomol. 15: $57-62$.

LIEBHERR J.K. 2006b: Recognition and description of Blackburnia kavanaughi, new species (Coleoptera: Carabidae, Platynini) from Kauai, Hawaii. J. N. Y. Entomol. Soc. 114: $17-27$.

LIEBHERR J.K. \& KRUSHELNYCKY P.D. 2007: Unfortunate encounters? Novel interactions of native Mecyclothorax, alien Trechus obtusus (Coleoptera: Carabidae), and Argentine ant (Linepithema humile, Hymenoptera: Formicidae) across a Hawaiian landscape. J. Insect Conserv. 11: 61-73.

LiebherR J.K. \& Short A.E.Z. 2006: Blackburnia riparia, new species (Coleoptera: Carabidae, Platynini): a novel element in the Hawaiian riparian insect fauna. J. N. Y. Entomol. Soc. 114: $1-16$.

Mani M.S. 1962: Introduction to High Altitude Entomology. Methuen, London, $302 \mathrm{pp}$.

Montgomery S.L. 1982: Biogeography of the moth genus Eupithecia in Oceania and the evolution of ambush predation in Hawaiian caterpillars (Lepidoptera: Deometridae). Entomol. Gener. 8: 27-34.

Oswald J.D. 1993: Revision and cladistic analysis of the world genera of the family Hemerobiidae (Insecta: Neuroptera). $J$. N. Y. Entomol. Soc. 101: 143-299.

OswaLd J.D. 1996: A new brachypterous Nusulala species from Costa Rica, with comments on the evolution of flightlessness in brown lacewings (Neuroptera: Hemerobiidae). Syst. Entomol. 21: 343-352.
Oтте D. 1994: The Crickets of Hawaii. The Orthopterist's Society at the Academy of Natural Sciences of Philadelphia, Philadelphia, 396 pp.

Penny N.D. \& Strum H. 1984: A flightless brown lacewing from Colombia. Spixiana 7: 19-22.

Perkins R.C.L. 1899: Neuroptera. In Sharp D. (ed.): Fauna Hawaiiensis. Zoology of the Sandwich (Hawaiian) Isles. Vol. 2, Part 2. Cambridge University Press, Cambridge, pp. 31-89.

Roff D.A. 1990: The evolution of flightlessness in insects. Biol. Monogr. 60: 389-421.

RUBINOFF D. \& HAINES W.P. 2005: Web-spinning caterpillar stalks snails. Science 309: 575.

Southwood T.R.E. 1977: Habitat, the templet for ecological strategies? J. Anim. Ecol. 46: 336-365.

SteHR F.W. 1987: Immature insects. Vol. 1. Kendall/Hunt, Dubuque, IA, 754 pp.

TAUber C.A. \& KraKauer A.H. 1997: Larval characteristics and generic placement of endemic Hawaiian hemerobiids (Neuroptera). Pacif. Sci. 51: 413-423.

Tauber C.A., Tauber M.J. \& Tauber M.J. 1991: Egg size and taxon: their influence on survival and development of chrysopid hatchlings after food and water deprivation. Can. J. Zool. 69: 2644-2650.

WAGNER D.L. \& LieBHERR J.K. 1992: Flightlessness in insects. Trends Ecol. Evol. 7: 216-220.

Zera A.J. \& Denno R.F. 1997: Physiology and ecology of dispersal polymorphism in insects. Annu. Rev. Entomol. 42: 207-231.

Zera A.J. \& Harshman L.G. 2001: The physiology of life history trade-offs in animals. Annu. Rev. Ecol. Syst. 32: 95-126.

Zimmermann E.C. 1940: Studies of Hawaiian Neuroptera. Proc. Haw. Entomol. Soc. 10: 487-510.

Zimmermann E.C. 1957: Insects of Hawaii. Ephemeroptera, Neuroptera, Trichoptera. Vol. 6. University of Hawaii Press, Honolulu, 209 pp.

Zimmermann E.C. 1970: Adaptive radiation in Hawaii with special reference to insects. Biotropica 2: 32-38.

Received May 2, 2007; revised and accepted July 10, 2007 
APPENDIX 1. Forewing characteristics and their correlation with hind-wing brachyptery (as measured by the ratio of the forewing and hindwing lengths). Mean \pm SD (min-max). Within each row, values followed by different letters differ significantly (ANOVA, Bonferroni's All Pairs Comparison; $\mathrm{p}<0.05)$.

\begin{tabular}{|c|c|c|c|}
\hline & Micromus longispinosus $(\mathrm{N}=9)$ & Intermediate $(\mathrm{N}=7)$ & Micromus usingeri $(\mathrm{N}=5)$ \\
\hline Length (L), mm & $7.16 \pm 0.62(6.16,7.88) a$ & $4.47 \pm 0.46(3.79,5.04) b$ & $3.60 \pm 0.60(3.08,4.38) \mathrm{c}$ \\
\hline Width (W), mm & $2.43 \pm 0.25(2.43,3.16) \mathrm{a}$ & $2.26 \pm 0.70(1.74,3.79) b$ & $1.62 \pm 0.12(1.5,1.8) \mathrm{c}$ \\
\hline Ratio (L : W) & $2.54 \pm 0.06(2.45,2.63) \mathrm{a}$ & $2.26 \pm 0.11(2.04,2.41) b$ & $2.24 \pm 0.24(2.04,2.52) b$ \\
\hline \multicolumn{4}{|l|}{ SUBCOSTAL TRACE } \\
\hline Veinlets leaving Sc, N & $21.44 \pm 3.88(15,27)$ & $18.43 \pm 3.82(12,24)$ & $18.2 \pm 4.89(11,24)$ \\
\hline Veinlets reaching $\mathrm{C}, \mathrm{N}$ & $40.00 \pm 2.00(32,46) \mathrm{a}$ & $29.86 \pm 2.79(26,33) b$ & $26.8 \pm 2.95(22,30) b$ \\
\hline sc-r crossveins, $\mathrm{N}$ & $2.44 \pm 1.59(1,6) \mathrm{a}$ & $4.71 \pm 4.79(0,13) \mathrm{ab}$ & $8.40 \pm 3.44(5,13) b$ \\
\hline \multicolumn{4}{|l|}{ RADIAL TRACE } \\
\hline Primary ORBs, $\mathrm{N}$ & $6.70 \pm 1.16(5,9)$ & $6.43 \pm 0.79(5,7)$ & $8.80 \pm 5.26(6,8)$ \\
\hline Primary \& secondary ORBs, N & $8.80 \pm 0.63(8,10)$ & $8.00 \pm 1.00(7,9)$ & $10.60 \pm 2.07(9,14)$ \\
\hline Veinlets on margin, $\mathrm{N}$ & $33.33 \pm 3.46(28,39) \mathrm{a}$ & $21.29 \pm 2.50(18,25) \mathrm{b}$ & $13.6 \pm 7.27(6,24) b$ \\
\hline Intraradial crossveins, $\mathrm{N}$ & $18.11 \pm 4.54(13,26) \mathrm{a}$ & $24.57 \pm 15.53(10,57) \mathrm{a}$ & $67.4 \pm 21.3(44,101) b$ \\
\hline $\mathrm{r}-\mathrm{m}$ crossveins, $\mathrm{N}$ & $3.11 \pm 0.33(3,4) \mathrm{a}$ & $3.57 \pm 0.79(3,5) \mathrm{a}$ & $6.80 \pm 2.68(4,11) b$ \\
\hline \multicolumn{4}{|l|}{ MEDIAL TRACE } \\
\hline Intramedial crossveins, $\mathrm{N}$ & $5.67 \pm 1.41(11,16) \mathrm{a}$ & $6.71 \pm 4.42(4,16) \mathrm{a}$ & $13.60 \pm 7.27(6,24) b$ \\
\hline Veinlets on margin, $\mathrm{N}$ & $13.32 \pm 1.72(11,16) \mathrm{a}$ & $9.71 \pm 1.11(8,11) b$ & $9.2 \pm 1.30(8,11) b$ \\
\hline m-cu crossveins, $\mathrm{N}$ & $3.00 \pm 1.12(1,4) \mathrm{a}$ & $3.86 \pm 1.07(2,5) \mathrm{a}$ & $6.20 \pm 1.79(5,9) b$ \\
\hline \multicolumn{4}{|l|}{ CUBITAL TRACE } \\
\hline Intracubital crossveins, $\mathrm{N}$ & $4.67 \pm 1.58(1,6)$ & $4.57 \pm 2.51(1,8)$ & $5.00 \pm 4.18(0,9)$ \\
\hline Veinlets on margin, $\mathrm{N}$ & $12.44 \pm 2.07(8,15) \mathrm{a}$ & $9.43 \pm 1.81(6,11) a b$ & $8.4 \pm 4.04(4,12) b$ \\
\hline cu-a crossveins, $\mathrm{N}$ & $0.78 \pm 0.44(0,1) \mathrm{a}$ & $1.57 \pm 0.79(1,3) \mathrm{a}$ & $3.6 \pm 2.07(1,6) b$ \\
\hline \multicolumn{4}{|l|}{ ANAL TRACE } \\
\hline Veinlets on margin, $\mathrm{N}$ & $10.89 \pm 1.83(7,14) \mathrm{a}$ & $9.14 \pm 1.22(7,11) a b$ & $6.8 \pm 1.30(6,9) b$ \\
\hline \multicolumn{4}{|l|}{ WIDTH OF VEINS/ } \\
\hline \multicolumn{4}{|l|}{ FOREWING WIDTH } \\
\hline $\mathrm{C}$ at sc3 & $0.012 \pm 0.003(0.005,0.015) \mathrm{a}$ & $0.019 \pm 0.002(0.016,0.023) \mathrm{b}$ & $0.026 \pm 0.004(0.022,0.033) c$ \\
\hline $\mathrm{Sc}$ at $\mathrm{sc} 3$ & $0.013 \pm 0.003(0.007,0.016) \mathrm{a}$ & $0.021 \pm 0.003(0.018,0.027) \mathrm{b}$ & $0.033 \pm 0.004(0.027,0.036) \mathrm{c}$ \\
\hline $\mathrm{sc} 3$ & $0.008 \pm 0.002(0.004,0.010) \mathrm{a}$ & $0.013 \pm 0.003(0.009,0.017) \mathrm{b}$ & $0.016 \pm 0.004(0.011,0.021) \mathrm{b}$ \\
\hline $\mathrm{R}$ at $\mathrm{ORB} 1$ & $0.014 \pm 0.001(0.012,0.016) \mathrm{a}$ & $0.019 \pm 0.003(0.015,0.023) b$ & $0.028 \pm 0.002(0.025,0.032) \mathrm{c}$ \\
\hline $\mathrm{R}$ at $\mathrm{ORB} 3$ & $0.012 \pm 0.002(0.010,0.014) \mathrm{a}$ & $0.018 \pm 0.004(0.011,0.023) \mathrm{b}$ & $0.024 \pm 0.006(0.018,0.031) \mathrm{c}$ \\
\hline $\mathrm{R}$ at last $\mathrm{ORB}$ & $0.011 \pm 0.002(0.009,0.014) \mathrm{a}$ & $0.018 \pm 0.003(0.015,0.022) \mathrm{ab}$ & $0.026 \pm 0.013(0.014,0.046) \mathrm{b}$ \\
\hline
\end{tabular}

Terms, abbreviations: a - anal; $\mathrm{C}$ - costa; cu - cubitus; $\mathrm{m}$ - media; ORB - oblique radial branch (Oswald, 1993); R, r - radius; Sc, sc - subcosta; sc3 - third veinlet from subcosta to costa; trace - region of the wing encompassed by one of five major veins, and all of its branches (Oswald, 1993).

APPENDIX 2. Hind wing characteristics and their correlation with hind-wing brachyptery (as measured by the ratio of the forewing and hindwing lengths). Mean \pm SD (min-max). Within each row, values followed by different letters differ significantly (ANOVA, Bonferroni's All Pairs Comparison; $\mathrm{p}<0.05)$.

\begin{tabular}{|c|c|c|c|}
\hline & Micromus longispinosus $(\mathrm{N}=9)$ & Intermediate $(\mathrm{N}=7)$ & $\begin{array}{c}\text { Micromus usingeri } \\
(\mathrm{N}=5 \text {, unless stated otherwise })\end{array}$ \\
\hline Length (L), mm & $6.43 \pm 0.55(5.62,7.09) \mathrm{a}$ & $2.74 \pm 0.64(1.98,3.63) b$ & $0.58 \pm 0.08(0.53,0.71) \mathrm{c}$ \\
\hline Width (W), mm & $2.36 \pm 0.24(2.00,2.66) \mathrm{a}$ & $0.91 \pm 0.22(0.63,1.25) b$ & $0.29 \pm 0.07(0.20,0.39) \mathrm{c}$ \\
\hline Ratio (L : W) & $2.77 \pm 0.09(2.67,2.94) \mathrm{a}$ & $2.99 \pm 0.17(2.68,3.24) \mathrm{a}$ & $2.05 \pm 0.43(1.64,2.72) b$ \\
\hline Ratio (Forewing L : Hindwing L) & $1.11 \pm 0.02(1.09,1.14) \mathrm{a}$ & $1.92 \pm 0.31(1.43,2.21) b$ & $6.23 \pm 0.68(5.59,7.19) \mathrm{c}$ \\
\hline \multicolumn{4}{|l|}{ SUBCOSTAL TRACE } \\
\hline Veinlets leaving Sc, $\mathrm{N}$ & $27.71 \pm 4.54(23,35) \mathrm{a}$ & $11.00 \pm 5.66(4,18) b$ & $0.6 \pm 1.34(0,3) \mathrm{c}$ \\
\hline sc-r crossveins, $\mathrm{N}$ & $0.89 \pm 1.69(0,5)$ & 0 & 0 \\
\hline $\mathrm{Sc}+\mathrm{R}$ fused $(2=$ no; $1=$ yes $)$ & $2.0 \pm 0 \mathrm{a}$ & $1.36 \pm 0.24(1,1.5) \mathrm{b}$ & $1.0 \pm 0 \mathrm{c}$ \\
\hline \multicolumn{4}{|l|}{ RADIAL TRACE } \\
\hline r-rs crossveins, $\mathrm{N}$ & $5.33 \pm 1.87(3,8) \mathrm{a}$ & $1.00 \pm 1.53(0,4) b$ & $0(\mathrm{~N}=3) \mathrm{b}$ \\
\hline Intraradial crossveins, $\mathrm{N}$ & $7.22 \pm 2.11(5,10) \mathrm{a}$ & $1.29 \pm 1.35(0,4) b$ & $0.10 \pm 0.22(0,0.5)(\mathrm{N}=3) \mathrm{b}$ \\
\hline Veinlets on margin, $\mathrm{N}$ & $22.33 \pm 3.0(16,26) \mathrm{a}$ & $6.43 \pm 3.46(2,12) b$ & $0.20 \pm 0.45(0,1)(\mathrm{N}=3) \mathrm{c}$ \\
\hline r-m crossveins, $\mathrm{N}$ & $3.00 \pm 0.5(2,4) \mathrm{a}$ & $0.71 \pm 0.95(0,2) \mathrm{b}$ & $0(\mathrm{~N}=3) \mathrm{b}$ \\
\hline \multicolumn{4}{|l|}{ MEDIAL TRACE } \\
\hline Intramedial crossveins, $\mathrm{N}$ & $4.44 \pm 1.81(2,7) \mathrm{a}$ & $0.14 \pm 0.38(0,1) b$ & $0(\mathrm{~N}=3) \mathrm{b}$ \\
\hline Veinlets on margin, $\mathrm{N}$ & $18.44 \pm 3.24(13,23) \mathrm{a}$ & $3.71 \pm 2.63(1,7) b$ & $0.40 \pm 0.89(0,2)(\mathrm{N}=3) \mathrm{b}$ \\
\hline $\mathrm{m}$-cu crossveins, $\mathrm{N}$ & $1.89 \pm 0.33(1,2) \mathrm{a}$ & $0.86 \pm 0.69(0,2) b$ & $0(\mathrm{~N}=3) \mathrm{c}$ \\
\hline \multicolumn{4}{|l|}{ CUBITAL TRACE } \\
\hline Intracubital crossveins, $\mathrm{N}$ & $2.00 \pm 0.5(1,3) \mathrm{a}$ & $0 \mathrm{~b}$ & $0(\mathrm{~N}=3) \mathrm{b}$ \\
\hline Veinlets on margin, $\mathrm{N}$ & $10.11 \pm 1.45(8,12) \mathrm{a}$ & $4.14 \pm 1.35(2,6) b$ & $0.20 \pm 0.45(0,1) \mathrm{c}$ \\
\hline cu-a crossveins, $\mathrm{N}$ & $1.44 \pm 1.53(1,2) \mathrm{a}$ & $0.14 \pm 0.38(0,1) b$ & $0(\mathrm{~N}=3) \mathrm{b}$ \\
\hline \multicolumn{4}{|l|}{ ANAL TRACE } \\
\hline Veinlets on margin, $\mathrm{N}$ & $7.33 \pm 1.32(5,10) a$ & $3.29 \pm 1.80(1,6) b$ & $0.20 \pm 0.45(0,1) \mathrm{c}$ \\
\hline
\end{tabular}

Abbreviations: $\mathrm{a}$ - anal; cu - cubitus; $\mathrm{m}$ - media; $\mathrm{R}, \mathrm{r}$ - radius; $\mathrm{rs}$ - radial sector; $\mathrm{Sc}$, sc - subcosta; trace - region of the wing encompassed by one of five major veins, and all of its branches (Oswald, 1993). 
APPENDIX 3. Body characteristics and their correlation with hind-wing brachyptery (as measured by the ratio of the forewing and hindwing lengths). Mean \pm SD (min-max, mm). Within each row, values followed by different letters differ significantly (ANOVA, Bonferroni's All Pairs Comparison; $\mathrm{p}<0.05)$.

\begin{tabular}{|c|c|c|c|c|}
\hline & $\begin{array}{l}\text { M. longispinosus } \\
(\mathrm{N}=9)\end{array}$ & $\begin{array}{l}\text { Intermediate } \\
\quad(\mathrm{N}=7)\end{array}$ & $\begin{array}{l}\text { M. usingeri } \\
\quad(\mathrm{N}=5)\end{array}$ & $\begin{array}{l}\text { Correlation with } \\
\text { hind-wing brachyptery }\end{array}$ \\
\hline Head, width & $0.96 \pm 0.04(0.89,1.01) \mathrm{a}$ & $0.88 \pm 0.05(0.79,0.93) b$ & $0.93 \pm 0.06(0.87,1) \mathrm{ab}$ & $\mathrm{R}=-0.020, \mathrm{P}=0.9317$ \\
\hline Eye, width & $0.16 \pm 0.01(0.15,0.192) \mathrm{a}$ & $0.14 \pm 0.01(0.124,0.159) \mathrm{b}$ & $0.15 \pm 0.018(0.13,0.17) \mathrm{ab}$ & $\mathrm{R}=-0.242, \mathrm{P}=0.2909$ \\
\hline Vertex, width & $0.63 \pm 0.03(0.59,0.66)$ & $0.59 \pm 0.05(0.52,0.67)$ & $0.64 \pm 0.03(0.62,0.68)$ & $\mathrm{R}=0.293, \mathrm{P}=0.1880$ \\
\hline Frons, length & $0.43 \pm 0.03(0.39,0.47) \mathrm{a}$ & $0.38 \pm 0.02(0.35,0.41) b$ & $0.38 \pm 0.04(0.32,0.43) b$ & $\mathrm{R}=-0.471, \mathrm{P}=0.0313$ \\
\hline Gena, length & $0.38 \pm 0.03(0.33,0.43)$ & $0.35 \pm 0.04(0.29,0.39)$ & $0.37 \pm 0.02(0.35,0.39)$ & $\mathrm{R}=-0.060, \mathrm{P}=0.7961$ \\
\hline Gena, width & $0.30 \pm 0.02(0.27,0.34) \mathrm{a}$ & $0.25 \pm 0.04(0.18,0.29) b$ & $0.29 \pm 0.04(0.25,0.35) \mathrm{ab}$ & $\mathrm{R}=-0.046, \mathrm{P}=0.8433$ \\
\hline Antenna, length & $6.56 \pm 0.53(5.55,7.21) a$ & $5.51 \pm 0.57(4.72,6.25) b$ & $4.73 \pm 1.02(4.12,6.54) b$ & $\mathrm{R}=-0.647, \mathrm{P}<0.0015$ \\
\hline Prothorax, length & $0.45 \pm 0.03(0.38,0.49)$ & $0.44 \pm 0.04(0.38,0.49)$ & $0.49 \pm 0.06(0.40,0.54)$ & $\mathrm{R}=0.468, \mathrm{P}=0.0322$ \\
\hline Prothorax, width & $0.79 \pm 0.05(0.69,0.85) \mathrm{a}$ & $0.73 \pm 0.05(0.66,0.81) a b$ & $0.71 \pm 0.04(0.66,0.76) \mathrm{b}$ & $\mathrm{R}=-0.429, \mathrm{P}=0.0525$ \\
\hline Mesothorax, length & $0.79 \pm 0.07(0.67,0.89) \mathrm{a}$ & $0.60 \pm 0.05(0.51,0.65) \mathrm{b}$ & $0.60 \pm 0.06(0.53,0.66) b$ & $\mathrm{R}=-0.514, \mathrm{P}=0.0172$ \\
\hline Mesothorax, width & $1.15 \pm 0.09(1.01,1.30) \mathrm{a}$ & $0.93 \pm 0.08(0.82,1.01) b$ & $0.95 \pm 0.10(0.84,1.10) b$ & $\mathrm{R}=-0.443, \mathrm{P}=0.0445$ \\
\hline Mesotibia, length & $1.11 \pm 0.17(0.81,1.31)$ & $1.04 \pm 0.07(0.98,1.16)$ & $0.91 \pm 0.15(0.75,1.05)$ & $\mathrm{R}=-0.442, \mathrm{P}=0.0584$ \\
\hline Metatibia, length & $1.99 \pm 0.13(1.8,2.21) \mathrm{a}$ & $1.71 \pm 0.20(1.41,2.04) b$ & $1.22 \pm 0.33(0.85,1.53) \mathrm{c}$ & $\mathrm{R}=-0.770, \mathrm{P}<0.0001$ \\
\hline Metafemur, length & $1.26 \pm 0.09(1.16,1.44)$ & $1.09 \pm 0.11(0.89,1.26)$ & $1.12 \pm 0.22(0.87,1.45)$ & $\mathrm{R}=-0.246, \mathrm{P}=0.2828$ \\
\hline
\end{tabular}

APPENDIX 4. Characteristics of the male terminalia, min-max, mm

\begin{tabular}{|c|c|c|c|}
\hline & Micromus longispinosus $(\mathrm{N}=4)$ & Intermediate $(\mathrm{N}=3)$ & Micromus usingeri $(\mathrm{N}=2)$ \\
\hline \multicolumn{4}{|l|}{ TERGITE $9+$ ECTOPROCT } \\
\hline T9, length (base to base of lobes) & $0.387,0.463$ & $0.350,0.395$ & $0.281,0.320$ \\
\hline Posterodorsal lobe, length & $0.185,0.277$ & $0.166,0.195$ & $0.121,0.139$ \\
\hline Posteroventral lobe, length & $0.480,0.574$ & $0.376,0.423$ & $0.224,0.227$ \\
\hline Lobes, width of base & $0.208,0.252$ & $0.201,0.271$ & $0.192,0.250$ \\
\hline Ratio, lobe length ventral : dorsal & $2.07,2.59$ & $2.13,2.40$ & $1.61,1.87$ \\
\hline Longest terminal seta, length & $0.272,0.319$ & $0.291,0.316$ & $0.177,0.211$ \\
\hline \multicolumn{4}{|l|}{ STERNITE 9} \\
\hline Length, ventral margin & $0.143,0.294$ & $0.180,0.383$ & $0.295,0.305$ \\
\hline Height, near apex & $0.129,0.221$ & $0.190,0.201$ & $0.203,0.212$ \\
\hline Longest seta, length & $0.215,0.289$ & $0.179,0.231$ & $0.184,0.244$ \\
\hline \multicolumn{4}{|l|}{ SEGMENT 8} \\
\hline Tergite, length, mesal & $0.134,0.261$ & $0.164,0.221$ & $0.191,0.208$ \\
\hline Tergite, height, mesal & $0.094,0.355$ & $0.188,0.293$ & $0.119,0.154$ \\
\hline Longest terminal seta, length & $0.231,0.259$ & $0.201,0.244$ & $0.179,0.233$ \\
\hline
\end{tabular}

APPENDIX 5. Comparison of first instar characteristics.

\begin{tabular}{lcc}
\hline \multirow{2}{*}{ Trait } & \multicolumn{2}{c}{ Mean $\pm \mathrm{SD}, \mathrm{mm}(\mathrm{min}-\mathrm{max})$} \\
\cline { 2 - 3 } & Micromus longispinosus $(\mathrm{N}=6)$ & $0.332 \pm 0.050(0.305,0.422)$ \\
Head, width & $0.309 \pm 0.010(0.290,0.320)$ & $0.287 \pm 0.043(0.260,0.364)$ \\
Head, length & $0.259 \pm 0.007(0.249,0.270)$ & $0.253 \pm 0.036(0.229,0.315)$ \\
Mandible, length & $0.244 \pm 0.140(0.224,0.260)$ & $0.376 \pm 0.070(0.337,0.501)$ \\
Antenna, length & $0.354 \pm 0.025(0.327,0.400)$ & $0.355 \pm 0.019(0.333,0.380)$ \\
Prothorax, width (dorsal) & $0.371 \pm 0.039(0.309,0.410)$ & $0.466 \pm 0.034(0.425,0.503)$ \\
Mesothorax, width (dorsal) & $0.485 \pm 0.086(0.343,0.561)$ & $0.471 \pm 0.040(0.427,0.519)$ \\
Metathorax, width (dorsal) & $0.506 \pm 0.082(0.379,0.589)$ & $0.769 \pm 0.062(0.675,0.825)$ \\
Thorax, length (lateral) ${ }^{1}$ & $0.914 \pm 0.060(0.790,0.975)$ & $1.270 \pm 0.053(1.214,1.321)$ \\
Abdomen, length & $1.585 \pm 0.189(1.350,1.769)$ & $2.44 \pm 0.11(2.32,2.55)$ \\
Body, length (lateral) $^{3}$ & $2.95 \pm 0.29(2.57,3.22)$ &
\end{tabular}

${ }^{1}$ Significant interspecific difference $(\mathrm{F}=13.236 ; \mathrm{P}=0.0054) ;{ }^{2}$ Significant interspecific difference $(\mathrm{F}=12.792 ; \mathrm{P}=0.0060) ;{ }^{3}$ Significant interspecific difference $(\mathrm{F}=13.290 ; \mathrm{P}=0.0054)$.

APPENDIX 6. Comparison of third instar characteristics.

\begin{tabular}{lcc}
\hline \multirow{2}{*}{ Trait } & \multicolumn{2}{c}{ Mean $\pm \mathrm{SD}, \mathrm{mm}(\mathrm{min}-\mathrm{max})$} \\
\cline { 2 - 3 } Head, width & Micromus longispinosus $(\mathrm{N}=6)$ & $0.476 \pm 0.012(0.465,0.496)$ \\
Head, length & $0.524 \pm 0.016(0.494,0.542)$ & $0.405 \pm 0.027(0.371,0.437)$ \\
Mandible, length & $0.470 \pm 0.028(0.435,0.520)$ & $0.320 \pm 0.027(0.281,0.349)$ \\
Antenna, length & $0.380 \pm 0.047(0.287,0.416)$ & $0.495 \pm 0.028(0.482,0.519)$ \\
Labial palp, length & $0.613 \pm 0.216(0.384,1.026)$ & $0.314 \pm 0.032(0.260,0.346)$ \\
Prothorax, width & $0.378 \pm 0.012(0.359,0.395)$ & $0.749 \pm 0.028(0.707,0.782)$ \\
Mesothorax, width & $0.961 \pm 0.166(0.807,1.243)$ & $1.093 \pm 0.043(1.044,1.142)$ \\
Metathorax, width & $1.346 \pm 0.275(1.112,1.834)$ & $1.174 \pm 0.055(1.101,1.224)$ \\
Thorax, length & $1.432 \pm 0.307(1.199,1.972)$ & $2.012 \pm 0.133(1.796,2.138)$ \\
Abdomen, length & $2.258 \pm 0.378(1.745,2.900)$ & $3.317 \pm 0.233(3.014,3.584)$ \\
Body, length ${ }^{1}$ & $3.762 \pm 0.776(2.367,4.634)$ & $6.071 \pm 0.380(5.472,6.469)$
\end{tabular}

${ }^{1}$ Significant interspecific difference $(\mathrm{F}=5.285 ; \mathrm{P}=0.047)$. 